OECD Science, Technology and Industry Working Papers 2002/09

\title{
Taxation, SMEs and Entrepreneurship
}

\section{Duanjie Chen,}

Franck Lee, Jack M. Mintz 
Organisation de Coopération et de Développement Economiques

Organisation for Economic Co-operation and Development

09-Aug-2002

DIRECTORATE FOR SCIENCE, TECHNOLOGY AND INDUSTRY

English - Or. English

STI Working Paper 2002/9

\section{INDUSTRY ISSUES}

TAXATION, SMES AND ENTREPRENEUSHIP

Duanjie Chen, Macrosys Research and Technology, Washington, DC Frank C. Lee, OECD, Paris and

Jack Mintz, University of Toronto and C.D. Howe Institute, Toronto 


\section{STI Working Paper Series}

The Working Paper series of the OECD Directorate for Science, Technology and Industry is designed to make available to a wider readership selected studies prepared by staff in the Directorate or by outside consultants working on OECD projects. The papers included in the series cover a broad range of issues, of both a technical and policy-analytical nature, in the areas of work of the DSTI. The Working Papers are generally available only in their original language - English or French - with a summary in the other.

Comment on the papers is invited, and should be sent to the Directorate for Science, Technology and Industry, OECD, 2 rue André Pascal, 75775 Paris Cedex 16, France.

The opinions expressed in these papers are the sole responsibility of the author(s) and do not necessarily reflect those of the OECD or of the governments of its Member countries.

http://www.oecd.org/sti/working-papers

Copyright OECD, 2002

Applications for permission to reproduce or translate all or part of this material should be made to:

OECD Publications, 2 rue André-Pascal, 75775 Paris, Cedex 16, France. 
DSTI/DOC(2002)9

\title{
TAXATION, SMEs AND ENTREPRENEURSHIP
}

\author{
Duanjie Chen, Macrosys Research and Technology, Washington, DC \\ Frank C. Lee, OECD, Paris and \\ Jack Mintz, University of Toronto and C.D. Howe Institute, Toronto ${ }^{1}$
}

This paper discusses the implications of tax policy for the growth of entrepreneurship and small and medium-sized enterprises (SMEs). Some existing features of OECD tax systems are biased against entrepreneurs and small firms. For instance, double taxation of distributed corporate profits can discourage incorporation of small firms while it can also favour debt over equity financing, the latter most required by SMEs. Conversely, a number of OECD countries have features in their tax systems that favour selfemployed individuals and SMEs to encourage growth. These include lower corporate income tax rates, exemptions from value-added taxes and investment tax credits. It is, however, not clear that the benefits of preferential tax treatment of self-employed individuals and SMEs outweigh the costs of moving away from tax neutrality. There are a number of areas where OECD governments can improve the tax climate for small firms and entrepreneurs. They can reduce progressivity in personal income tax rate schedules, which penalises successful entrepreneurs and discourages risk-taking. They can lower taxes on income earned by entrepreneurs (capital gains, dividends and other income), which may discourage entrepreneurs, and remove the tax bias favouring longer-term assets, which can hinder the reallocation of capital towards start-ups. More liberal provisions for carrying-forward losses in corporate income tax would assist startups which take more time to become profitable. Governments also need to continue efforts to minimise tax compliance and administrative costs, which are especially burdensome for small firms.

1. The authors are grateful to Paul Atkinson, Peter Avery, Louis Beauséjour, Christopher Heady, Brian Fields, Michael Freudenberg, Daniel Malkin, Takayuki Matsuo, Bob Morrison and Candice Stevens for useful comments. 


\title{
FISCALITE, PME ET ENTREPRENARIAT
}

\author{
Duanjie Chen, Macrosys Research and Technology, Washington, DC \\ Frank C. Lee, OCDE, Paris, et \\ Jack Mintz, Université de Toronto et Institut C.D. Howe, Toronto ${ }^{2}$
}

Le présent document traite des effets de la politique fiscale sur l'entreprenariat et les PME. Les systèmes fiscaux en vigueur dans les pays Membres de l'OCDE présentent parfois des aspects qui pénalisent les entrepreneurs et les petites entreprises. A titre d'exemple, la double imposition des bénéfices distribués peut dissuader les petites entreprises de se constituer en sociétés anonymes, ou peut favoriser l'endettement au détriment du financement par augmentation des fonds propres, ce dont ont le plus besoin les PME. A l'inverse, un certain nombre de pays Membres de l'OCDE ont mis en place, pour stimuler la croissance, des mesures fiscales en faveur des travailleurs indépendants et des PME : baisse des taux de l'impôt sur les sociétés, exonération de la taxe sur la valeur ajoutée et crédit d'impôt pour les investissements, par exemple. Il n'est pas évident toutefois que les avantages de ce traitement fiscal préférentiel à l'intention des travailleurs indépendants et des PME l'emportent sur les coûts induits par l'abandon de la neutralité fiscale. Il y a plusieurs domaines où les gouvernements des pays Membres de l'OCDE peuvent améliorer l'environnement fiscal des petites entreprises et des entrepreneurs : ils peuvent réduire la progressivité des barèmes de l'impôt sur le revenu des personnes physiques, qui a pour effet de pénaliser les chefs d'entreprise et de les dissuader de prendre des risques. Ils ont aussi la possibilité d'abaisser l'impôt sur le revenu gagné par des entrepreneurs (plus-values, dividendes et autres produits), qui peut décourager les entrepreneurs, ou de supprimer les mesures fiscales favorables aux actifs à long terme, qui peuvent faire obstacle à la réaffectation du capital vers les jeunes entreprises. Une plus grande souplesse des dispositions relatives au report des pertes aiderait les jeunes entreprises qui ont besoin d'un peu plus de temps pour être rentables. Les pouvoirs publics doivent aussi poursuivre leurs efforts pour minimiser les frais administratifs et les coûts associés au respect des obligations fiscales, particulièrement pesants pour les petites entreprises.

2. Les auteurs expriment leur gratitude à Paul Atkinson, Peter Avery, Louis Beauséjour, Christopher Heady, Brian Fields, Michael Freudenberg, Daniel Malkin, Takayuki Matsuo, Bob Morrison et Candice Stevens pour leurs précieuses observations. 


\section{TABLE OF CONTENTS}

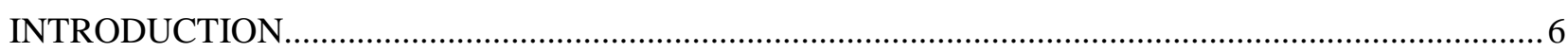

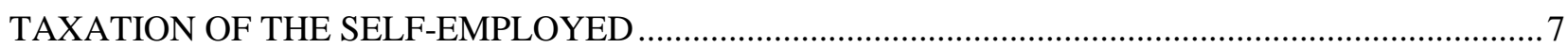

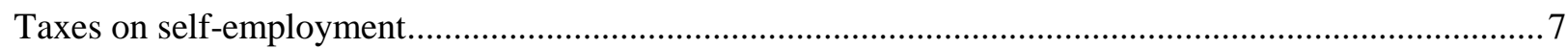

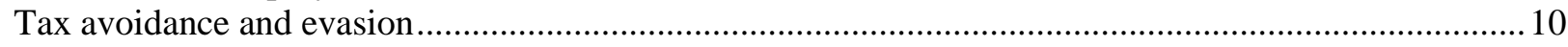

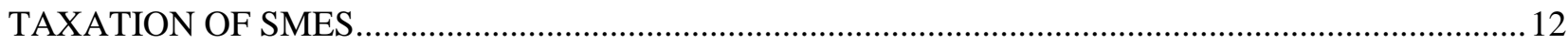

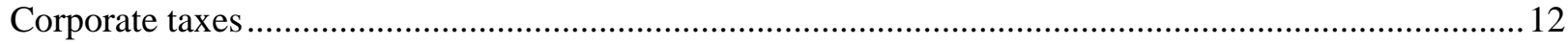

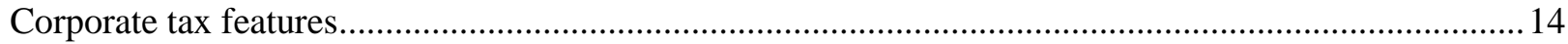

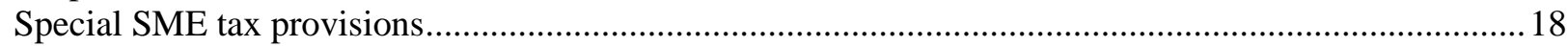

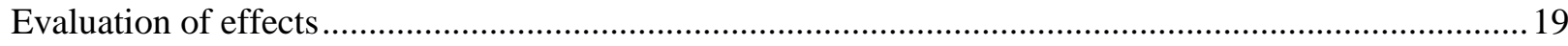

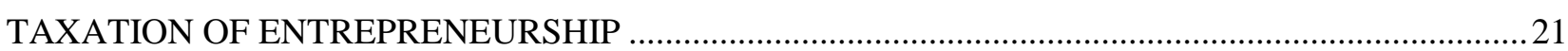

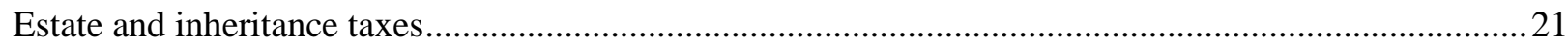

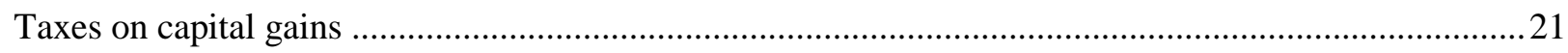

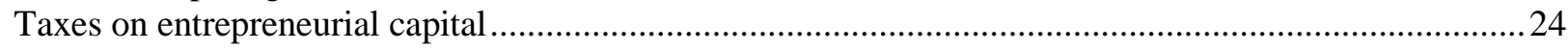

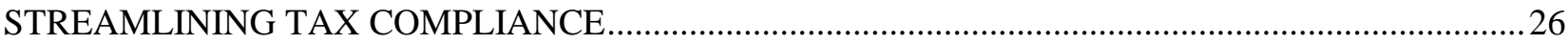

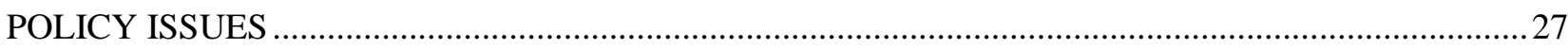

ANNEX A. METHODOLOGY FOR ESTIMATING EFFECTIVE TAX RATE ON CAPITAL ..............29

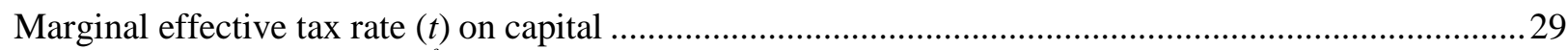

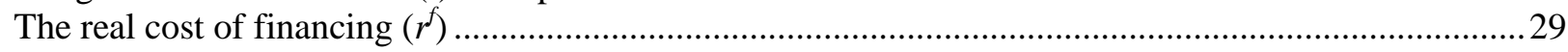

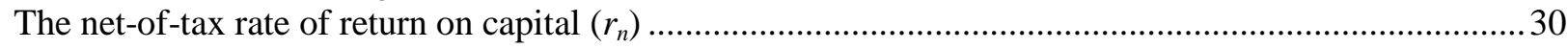

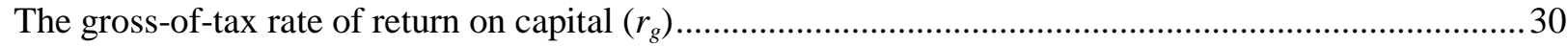

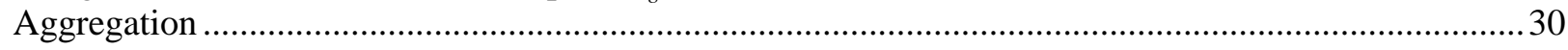

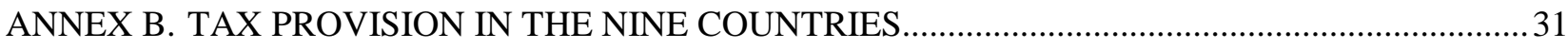

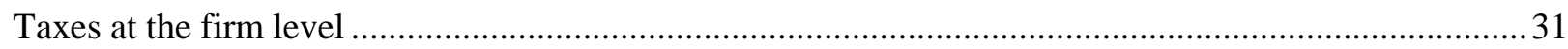

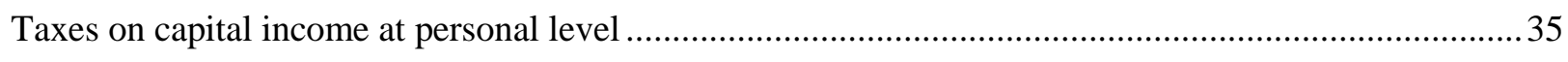

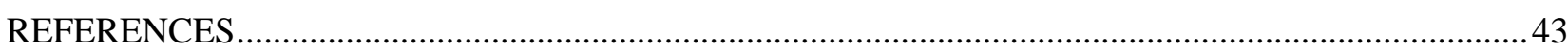

\section{Boxes}

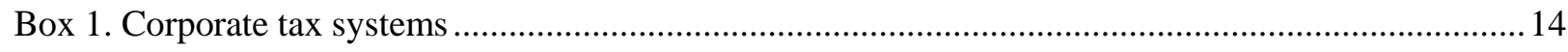




\section{INTRODUCTION}

Tax policy is one of the most potent policy instruments for governments to achieve the dual objectives of equity and efficiency. Taxes are raised to finance public goods and services that are needed to support growth and provide economic opportunities to all citizens. However, the burden of taxes can adversely affect economic growth by discouraging new investment, work effort, skill acquisitions and entrepreneurial incentives (Engen and Skinner, 1996). Thus, one of the key challenges facing governments is to design an efficient, fair and simple tax system that is conducive to economic growth.

Some theoretical and empirical studies have assessed the role of tax policy in economic growth (see Leibfritz et al., 1997). Within this literature, there is growing interest in tax policy as it relates to entrepreneurship (e.g. Robson and Wren, 1999; Bruce, 2000; and Carroll et al., 2000a, 2000b). Entrepreneurs are defined for purposes below as individuals who are engaged with the creation and development of new products and techniques of production, whether it is the innovator himself or managers who help bring the idea successfully to the market. Entrepreneurs are often identified with startup companies but they could easily be operating in a large company that continually develops new ideas for the business. The health and vitality of entrepreneurship is increasingly viewed as one of the key ingredients for generating economic growth (OECD, 2001c, 2001d). Consequently, most OECD governments provide fiscal incentives and tax breaks to the self-employed and SMEs to raise the level of entrepreneurship. This type of government support is based on the perceptions that the supply of entrepreneurship is insufficient, and that the self-employed and SMEs are important sources of entrepreneurship and innovation.

It is, however, inappropriate to assume that self-employment and SMEs are equivalent to the number of potentially high-growth start-ups with which most people identify entrepreneurship. Although some self-employed individuals and SMEs display traits that characterise entrepreneurship - flexibility, speed, risk taking and innovation, - the nature of the businesses which most small companies and self-employed persons are in suggests that the majority have limited growth potential. Some countries give preferential tax treatment to the self-employed and SMEs based on the claim that they create a majority of jobs. Although this claim is disputable, more fundamentally, it is not so much that the self-employed and SMEs create jobs, but rather that start-ups generate many jobs and a majority of start-up firms happen to be small (Gravelle, 1994).

A number of OECD countries have special tax provisions for the self-employed and SMEs in addition to having incomplete integration between personal and corporate tax systems. Consequently, tax systems in OECD countries are not neutral, affecting decisions regarding organisational form, corporate capital structure and corporate dividend distributions (Hubbard, 1993). Other distortions include the choice between labour, capital, and training of employees. The resulting non-neutral tax systems are often inefficient, distorting the allocation of resources. The favourable tax treatment of the self-employed and SMEs can be justified on efficiency grounds if there are spillover (external) effects to the rest of the economy. Consequently, governments need to review tax bias against entrepreneurs and to design tax policies for entrepreneurship to remedy market failures while avoiding adverse side-effects.

The objective of this paper is to compare tax provisions related to self-employment and SMEs across OECD countries, and discuss their implications for the growth of entrepreneurship. The following section analyses taxes on the self-employed. The next two sections discuss taxes on SMEs and entrepreneurship respectively. The remaining sections discuss policy implications. 
DSTI/DOC(2002)9

\section{TAXATION OF THE SELF-EMPLOYED}

\section{Taxes on self-employment}

Taxation of individuals who are self-employed can affect levels of entrepreneurship in a number of ways. For instance, self-employed individuals who are involved in starting businesses are subject to personal income tax while their reinvested earnings in the firm could be subject to capital gains tax at the disposition of their assets. Moreover, if these individuals decide to incorporate their firms, then their retained earnings are taxed according to corporate tax rates and their distributed earnings are taxed according to personal tax rates in most countries. Generally speaking, small firms are owner-operated and subject to personal income tax, while the earnings of incorporated SMEs are subject to corporate tax. The implications of personal income tax for self-employment is discussed in this section, while the role of corporate income tax is analysed in the next section.

In most OECD countries, income from self-employment is taxed as ordinary income at a progressive personal income tax rate after deductions for business expenses. On the other hand, Denmark, Finland, Norway and Sweden operate dual income tax systems (DIT), under which self-employment income is split into its capital and labour components. ${ }^{3}$ Capital income is taxed at the single fixed capital income tax rate and labour income is subject to the progressive structure of the personal income tax system. In part, the dual income tax reflects a concern that capital income is a very mobile tax base and needs to be taxed at a lower rate.

Studies generally find that lower personal income taxes can increase self-employment. Fairlie and Meyer (1999) observe that the tax rate fell with the rise in self-employment in the United States in the 1980s. They attribute the upturn in self-employment to an industrial shift from low to high selfemployment industries possibly driven by increased globalisation and advances in technology. Several studies (Carroll et al., 2000a, 2000b, 2001,; Holtz-Eakin and Rosen, 2001) conclude that entrepreneurs responded positively to tax incentives in the United States in the 1980s. After controlling for firm survival, they found that lower marginal personal tax rates induced small enterprises to grow faster, hire more workers and invest more heavily in equipment and structures. At the same time, corporate taxation can discourage the incorporation of profitable businesses. Self-employed individuals facing lower personal income tax rates than corporate tax rates have an incentive to remain self-employed in order to reduce their tax burden.

It is not only the level of tax rates, but also tax structures that influence the behaviour of potential entrepreneurs. Flatter structures may induce higher self-employment. There is greater variability in the returns to self-employed than the returns to working for someone else, indicating that entrepreneurs may face greater mobility in income distribution. Consequently, entrepreneurs are more sensitive to tax schedule and progressive income tax structure (Gentry and Hubbard, 2000). Increasing the progressivity of the tax system allows government to take a larger share of the pie as entrepreneurs become more successful thereby discouraging entrepreneurial entry. Moreover, progressivity of rate schedules imposes a tax on risky investments. Entrepreneurs investing at low points of the cycle will have little income and a low rate of tax for deductions. However, as their investments bear fruits, their income would be subject to higher tax rates.

3. This dual system also applies a lower rate on company income and a higher rate on labour income. 
Figure 1 compares combined top statutory tax rates on labour income between employees and the self-employed, i.e. taxes imposed by central government and sub-central government, surcharges as well as social security charges. A comparison of marginal combined tax rates between employees and the selfemployed shows that there is no substantial difference between the two different categories of workers for most OECD countries. However, the self-employed are effectively taxed at a lower rate in, for example, the Nordic countries, where business income of the self-employed is taxed at the capital income tax rate. Moreover, in some OECD countries, such as in the Czech Republic and Portugal, the self-employed face lower combined tax rates compared to employees due to the fact that the existing social security system favours the self-employed, thereby providing a strong incentive to become self-employed (Bronchi and Burns, 2000; Bronchi and Gomes-Santos, 2001).

Figure 1. Marginal combined tax rates of top income earners, 2000

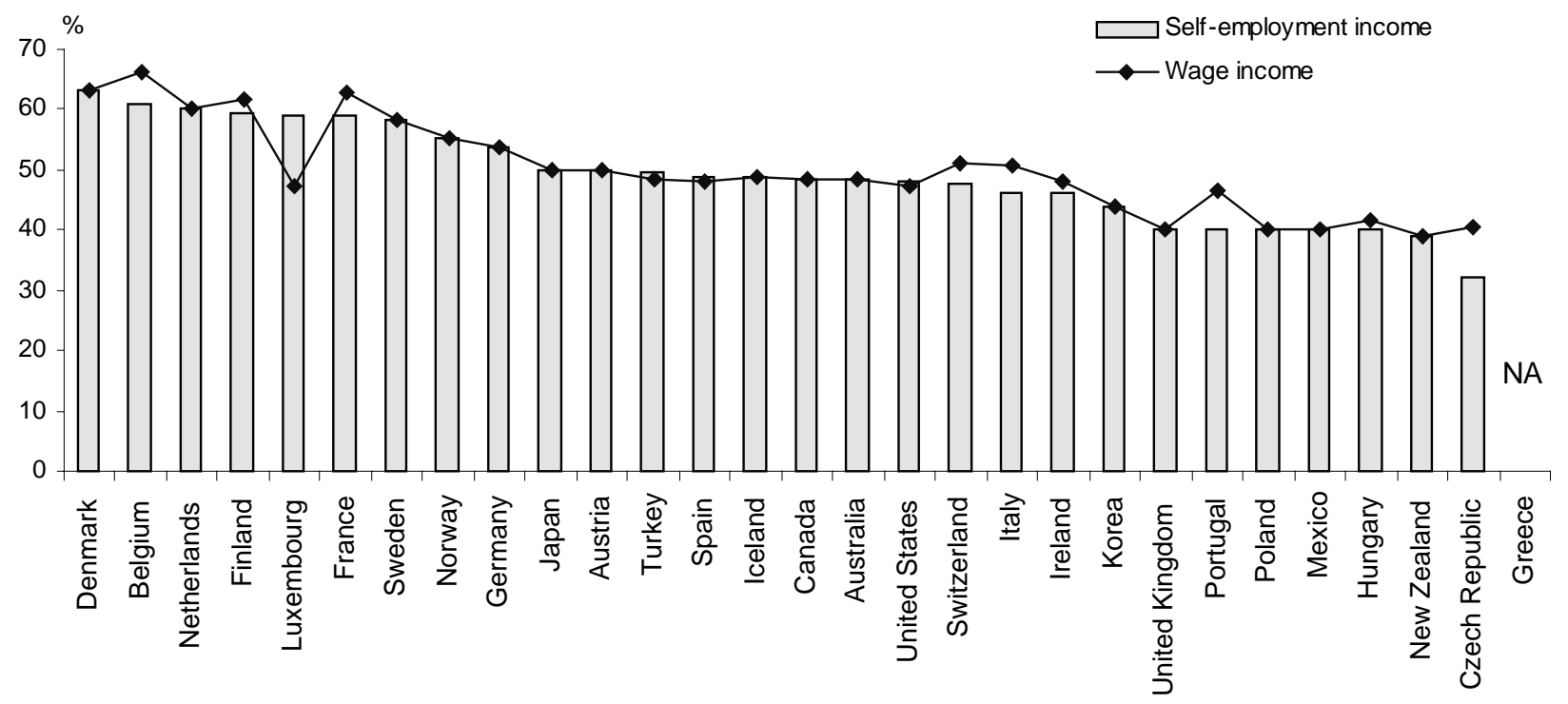

Note: The rates include taxes imposed by central and sub-central governments, surcharges and social security contributions. The rate for the capital component of income is $56.6 \%$ and $18 \%$ for Germany and Hungary, respectively. Source: OECD (2001e).

In the Czech Republic, lower taxes paid by the self-employed compared to wage earners stem from two features of the social security system (Bronchi and Burns, 2000). First, social contributions are based on a smaller tax base for the self-employed (35\% of yearly income net of expenses). Second, there is an upper contribution ceiling for the self-employed which further lowers the actual contributions made by the self-employed. The self-employed pay only half as much as employees in income taxes and social security contributions on a per capita basis. In Portugal, the self-employed pay the highest legal rate to benefit from the broad coverage of the social security system. However, they minimise social security contributions by selecting the low base (Bronchi and Gomes-Santos, 2001). It is thus common for senior employees in both countries to set up as independent consultants to take advantage of the existing tax bias favouring the selfemployed. In Greece, the self-employed pay between $15 \%$ and $37 \%$ of the gross earnings of an average production worker to the social security system, while employees and employers together contribute $44 \%$ of gross wages to the system. At the same time, some special categories of self-employed are either exempt or supplemented by other sources (Bronchi, 2001). The contributions made by self-employed to the social security system amount to very little across OECD countries due either to the tax advantage inherent in the 
social security system or to lower reported income by the self-employed (Figure 2). ${ }^{4}$ For instance, For instance, the self-employed in the OECD contribute roughly 7 per cent of the social security system whereas they account for 15 per cent of civilian employment. ${ }^{5}$

Figure 2. Social security contributions by payer, 2000

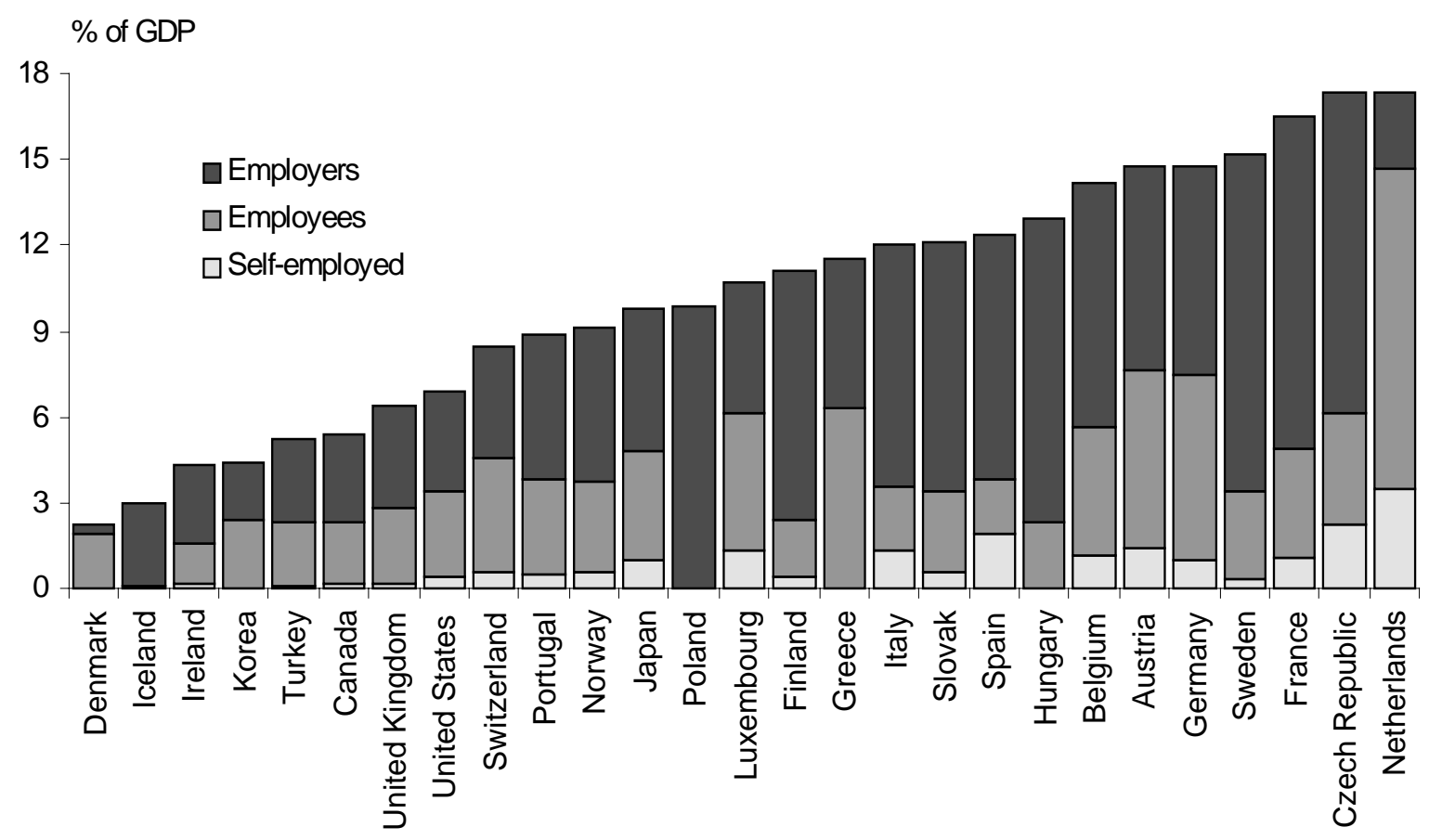

Notes:

1. 1997 for the Netherlands.

2. 1999 for Denmark, Iceland, Japan, Poland and the United States.

Source: OECD (2001b).

In addition to the social security system, other special tax provisions for the self-employed suggest that income from the self-employed is taxed at lower effective rates than income from wage earners. For example, the self-employed often qualify for simplified tax regimes. In Portugal, the self-employed with yearly incomes of less than PTE 30 million are not obliged to do book-keeping, rather they are taxed based on coefficients fixed by law (Bronchi and Gomes-Santos, 2001). The self-employed in Hungary, Mexico and Spain have access to special simplified tax regimes. The self-employed in Korea are allowed to split their incomes between themselves and other members of their families, thereby allowing the possibility of lowering effective tax rates for the household (Dalsgaard, 2000a).

4. Another reason for a lower social security burden faced by self-employed is that there may be an advantage to incorporation as income rises resulting in only low-income businesses being unincorporated.

5. Based on a sample of twenty two OECD countries. 
DSTI/DOC(2002)9

\section{Tax avoidance and evasion}

Certain features of taxation of the self-employed are believed to create loopholes which could lead to tax avoidance or evasion. First, the taxation of self-employment income is based on voluntary compliance whereas taxes on wages and salaries are withheld, leading many to believe that there is a greater room for the self-employed to avoid or evade taxes. Second, personal expenses could be misreported as business expenses by the self-employed. Consequently, there is a greater scope for the self-employed to reduce their taxable income and receive personal benefits from these deductions.

These features of the tax system can encourage the self-employed to underreport their taxable income. However, the extent of underreporting varies across countries depending on the specific tax rules and the strength of the tax audit. Japanese evidence suggests that the underreporting of income is more severe among the self-employed than among wage earners (Dalsgaard and Kawagoe, 2000). Similarly, the selfemployed are found to be more likely to evade taxes based on Minnesota income tax returns (Blumenthal et al., 1998). Furthermore, higher marginal tax rates are positively associated with tax evasion among the self-employed in the United States (Joulfaian and Rider, 1998). ${ }^{6}$ For some countries, the difference between income reported and actual income is estimated to be substantial, with the actual income of the self-employed exceeding reported income by up to 50\% in Korea (Dalsgaard, 2000a). In Mexico, the self-employed end up paying almost no tax, while $26 \%$ of the self-employed declared taxable income below the minimum wage in Portugal (Bronchi and Gomes-Santos, 2001; Dalsgaard, 2000b).

The greater tax avoidance opportunity by the self-employed could induce individuals to become selfemployed with increases in income tax rates. This is because the gains from tax avoidance for the selfemployed are higher with higher income tax rates. ${ }^{7}$ Studies based on US and UK data suggest that there is a greater possibility for the self-employed to avoid and/or evade taxes. Therefore, some studies find a perverse relationship whereby increased income tax rates raised the self-employment rate (Long, 1982; Blau, 1987; Evans and Leighton, 1989; Parker, 1996; Robson, 1998). Higher tax rates increase the entry into self-employment while reducing the probability of leaving self-employment (Bruce, 2000, 2001). One of the channels by which entry occurs is through the formation of small businesses by wage earners to take advantage of the tax benefits without giving up their main wage earning jobs. This essentially reduces the average share of effort directed towards the entrepreneurial venture (Bruce and Holtz-Eakin, 2001). Or put more simply, higher tax rates reduce the desired level of work effort. Thus, a simple counting exercise may suggest an increase in the number of self-employment with increases in the personal income tax rate. However, such increases may not have the desired benefits associated with the true state of entrepreneurship.

Government might give tax breaks to help small businesses overcome market failures, compliance costs and tax distortions that would otherwise appear in the tax systems. On the other hand, tax preferences could result in unwelcome distortions - people deciding to become self-employed rather than remaining employed, recharacterising personal income as tax-favoured business income, or misreporting income or expenses. Governments, therefore, need to take into account loopholes, tax avoidance and evasion in designing tax policies to encourage entrepreneurship. In countries where there are many opportunities for the self-employed to avoid and evade taxes, higher tax rates may induce wage and

6. It is not clear whether the relevant tax effects should operate through average tax rates (ATRs) or marginal tax rates (MTRs). If the decision to continue in self-employment is primarily an all-or-nothing decision, ATRs are most appropriate. However, if individuals typically approach this by deciding where to allocate their next hour of labour supply, MTRs are preferred (Bruce, 2001).

7. This implicitly assumes that the self-employed and employees are taxed at the same statutory tax rates. If the self-employed are taxed at a lower rate than employees, then this favourable tax treatment of the selfemployed would induce employees to become self-employed. 
salaried workers to become self-employed. Thus, governments should first reduce the opportunity for tax avoidance and evasion by the self-employed. This would increase the fairness of the tax system and reduce rent-seeking behaviour (in search of opportunities for tax avoidance) by potential entrepreneurs. The decision to become an entrepreneur would then be made on the basis of the perceived economic gains rather than by distortions created by taxes. ${ }^{8}$

8. Higher marginal personal income tax rates raise labour market distortions by widening the wedge between the real production wage and the real consumption wage. In fact, the total labour market distortion and its effect on employment and potential output is determined by tax wedges and elasticities of labour demand and supply (Dalsgaard, 2000b). For instance, in countries with flexible real wages, taxes are shifted to labour, reducing the take-home pay, while leaving labour demand relatively unaffected. In this case, low labour supply elasticities would reduce the extent of the fall in employment. 


\section{TAXATION OF SMES}

\section{Corporate taxes}

Corporate tax rates can influence investment and financing decisions, as well as the choice of organisational form. Corporate tax rates which are below top marginal personal income tax rates - along with provisions for deferral of personal taxation through reinvestment of profits - can provide incentives for the self-employed to incorporate their businesses (King, 1977). A decrease in the rate of corporate tax increases the incentives for incorporation, ceteris paribus, and results in a lower level of self-employment than might otherwise have been the case (Robson, 1998). This type of tax induced changes in the form of organisation may trigger income shifting in the form of compensation without affecting the real activity. Ignoring the presence of market failures and externalities, such a tax system distorts the allocation of resources and reduces economic efficiency (Gordon, 1998). At the same time, there are advantages associated with reduced tax rates on SMEs: increased after-tax earnings and thus a lower cost of equity funds, increased equity investment and reduced tax distortion in favour of debt.

Many OECD countries have lower tax rates for SMEs to foster their competitiveness (Table 1). These include Belgium, Canada, France, Germany, Ireland, Japan, Korea, Luxembourg, Mexico, the Netherlands, Portugal, Spain, the United Kingdom and the United States. ${ }^{9}$ These measures are often motivated by both efficiency and equity objectives. The efficiency objectives are based on the notion that small businesses are prone to market failure, for example, due to higher compliance costs with regulations associated with diseconomies of scale and reduced access to financing, necessitating government policy. The equity objectives are in part motivated by the lower the profits earned by SMEs.

Favourable corporate tax treatment of SMEs may encourage underreporting of income or lead entrepreneurs to divide businesses into separate corporations for tax purposes. Lower corporate tax rates which can help address market failures in the availability of SME finance, should perhaps be accompanied by anti-fragmentation rules to prevent larger firms from artificial tax-induced divisions. For example, the United Kingdom has special rules to prevent businesses from establishing very small companies in order to benefit from the $10 \%$ corporate tax rate. Canada also has "associated corporation" rules to address this issue.

9. The U.S. allows profits and losses of S-type corporations to pass through to shareholders (i.e., taxes only at the personal level), thereby avoiding double taxation of corporate profits. However, they accept other restrictions in exchange for avoiding the corporate level taxation (Carroll and Joulfaian, 1997). Scorporations could have no more than 75 shareholders. 
DSTI/DOC(2002)9

Table 1. Taxation of corporate income, 2000

\begin{tabular}{|c|c|c|c|c|c|}
\hline \multicolumn{4}{|c|}{ Central government corporate taxes } & \multirow{2}{*}{$\begin{array}{l}\text { Combined } \\
\text { Tax rate }^{1}\end{array}$} & \multirow{2}{*}{$\begin{array}{c}\text { Combined } \\
\text { tax rate for } \\
\text { SMEs }^{1}\end{array}$} \\
\hline & Basic & SMEs & Definition of SMEs & & \\
\hline \multicolumn{6}{|c|}{ Countries with lower tax rates for SMEs } \\
\hline Belgium & 40.2 & 28.84 & Income < EUR 24,789 & 40.2 & 28.84 \\
\hline Canada $^{2}$ & 29.12 & 13.12 & Income < CAD $200000^{3}$ & 43.2 & 20.7 \\
\hline France & 33.3 & 19 & Turnover less than FF 50 million & 41.7 & 30 \\
\hline Greece & 40 & 25 & For limited partnerships & 40 & 25 \\
\hline Ireland & 24 & 12.5 & Trading income $<$ IEP 200,000. & 24 & 12.5 \\
\hline Japan & 30 & 22 & Income below JPY 8 million & 40.9 & 33.3 \\
\hline Korea & 28 & 16 & Income below KRW 100 million & 30.8 & n.a. \\
\hline Luxembourg & 30 & 20 & For low income & 39.6 & n.a. \\
\hline Mexico & 35 & $0-2.5^{4}$ & 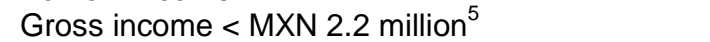 & 35 & $0-2.5$ \\
\hline Netherlands & 35 & 30 & First NLG 50000 of taxable income & 35 & 30 \\
\hline Portugal & 32 & 20 & Turnover < PET 30 million & 35.2 & n.a. \\
\hline Spain & 35 & 30 & Turnover < ESP 250 million & 35 & 30 \\
\hline UK & 30 & $10-20$ & Profits up to GBP 10000 and 50000 to $300000^{6}$ & 30 & $10-20$ \\
\hline US & 35 & 15 & Taxable income $<$ USD $335000^{7}$ & 39.5 & n.a. \\
\hline \multicolumn{6}{|c|}{ Countries with no special tax rates for SMEs } \\
\hline Australia & 34 & .. & & 34 & .. \\
\hline Austria & 34 & $\begin{array}{l}. . \\
. .\end{array}$ & & 34 & $\begin{array}{l}. . \\
. .\end{array}$ \\
\hline Czech Rep & 31 & $\begin{array}{l}. . \\
. .\end{array}$ & & 31 & $\begin{array}{l}. . \\
. .\end{array}$ \\
\hline Denmark & 32 & $\begin{array}{l}. . \\
. .\end{array}$ & & 32 & $\begin{array}{l}. . \\
. .\end{array}$ \\
\hline Finland & 29 & $\begin{array}{l}. . \\
. .\end{array}$ & & 29 & $\begin{array}{l}. . \\
. .\end{array}$ \\
\hline Germany & $40^{8}$ & $\begin{array}{l}. . \\
. .\end{array}$ & & 54 & $\begin{array}{l}. . \\
. .\end{array}$ \\
\hline Hungary & 18 & .. & & 18 & .. \\
\hline Iceland & 30 & $\begin{array}{l}. . \\
.\end{array}$ & & 30 & $\begin{array}{l}. . \\
. .\end{array}$ \\
\hline Italy & 37 & $\begin{array}{l}. . \\
. .\end{array}$ & & $41.3-45.5^{9}$ & $\begin{array}{l}. . \\
. .\end{array}$ \\
\hline New Zealand & 33 & $\begin{array}{l}. . \\
. .\end{array}$ & & 33 & $\begin{array}{l}. . \\
. .\end{array}$ \\
\hline Norway & 28 & $\begin{array}{l}. \\
. .\end{array}$ & & 28 & .. \\
\hline Poland & 30 & .. & & 30 & .. \\
\hline Sweden & 28 & $\begin{array}{l}. . \\
. .\end{array}$ & & 28 & .. \\
\hline Switzerland & 8.5 & $\begin{array}{l}. . \\
. .\end{array}$ & & 29.4 & ... \\
\hline Turkey & 33 & .. & & 44.1 & .. \\
\hline
\end{tabular}

Notes:

1. Combined rates include surcharges and sub-central rates where applicable.

2. Canadian corporate tax rate reductions will see the federal basic tax rate fall to $22.12 \%$ by 2004 and the average combined tax rate decrease to about 32\% by 2005.

3. For Canadian-controlled.

4. On gross income.

5. After a deduction of three times the minimum wage.

6. Graduated rates rising from $10 \%$ at GBP 10000 to $20 \%$ at GBP 50000 . This rate rises further from $20 \%$ at GBP 300000 to reach $30 \%$ basic rate at GBP 1.5 million.

7. Receive partial benefit from the graduated rates of $15 \%$ and $25 \%$ that apply to the first USD 75000 of taxable income.

8. On retained profits; $30 \%$ on distributed profits; reduced to $25 \%$ in 2001 .

9. Companies are subject to a regional tax on production activities (IRAP) at a rate of $4.25 \%$ for manufacturing firms and $8.5 \%$ for non-manufacturing firms.

Source: Ernst and Young (2001b), OECD (2001e), National sources. 


\section{Corporate tax features}

Despite lower corporate tax rates for SMEs in many countries, several features of the corporate tax system discriminate against smaller firms. ${ }^{10}$ A particular problem for SMEs/entrepreneurship is double taxation of dividends. Such double taxation occurs when income subject to corporate tax may also eventually be subject to additional personal taxes, either when profits are distributed in the form of dividends or when shares are issued and sold (capital gains). The personal tax on dividends and capital gains can be viewed as a tax on savings whereas the corporate income tax can be classified as a tax on investment (Boadway and Bruce, 1992). Thus, taxes on both dividends and capital gains are relevant in the context of firm organisational choices.

\section{Box 1. Corporate tax systems}

Corporate tax systems in OECD countries can be defined on the basis of their treatments of distributed profits (dividends) vis-à-vis the taxation of retained profits.

Full classical system. The company is subject to corporate tax while the shareholders are liable to personal income tax (or a withholding tax) on dividends. There is no attempt to relieve the shareholders for tax paid by the company. Thus, dividends are taxed twice under this system (e.g. Luxembourg, the Netherlands, Switzerland, the United States).

Modified classical system. Dividends are subject to a lower tax rate to relieve the shareholders for some portion of the tax paid by the company (e.g. Austria, Belgium, Iceland, Japan, Poland).

Imputation system. Part of the corporate tax paid on distributed profits is imputed to the shareholders and regarded as pre-payment of their personal income tax on dividends. Thus, shareholders are liable for the difference between their personal marginal rates of income tax and the rate of imputation (e.g. Australia, Finland, France, Mexico, New Zealand, Spain).

Partial credit system. The shareholder receives a partial credit for corporate tax paid on dividends against personal tax liability (e.g. Canada, Denmark, Korea, Portugal).

Partial deduction system. The company deducts from its corporate tax liability a fixed share of the withholding tax on dividends (e.g. the Czech Republic).

Exemption system. Under this system, dividends are exempt from personal income tax (e.g. Greece).

10. Payroll taxes are not discussed in this paper since there is a dearth of empirical studies on the effect of payroll taxes by business size (Lin, 2001). However, it is generally recognised that payroll taxes affect smaller firms more than larger firms in terms of administration and cost (Baran, 1996). It may be more appropriate to consider social security charges net of benefits in comparing tax rates across countries. For instance, the continental European countries have public pension plans and few private pension plans. Payroll taxes do not appear to be as problematic since, without the programme, people would have to pay for their own plan. 
In about half of OECD countries, top personal income tax rates are lower than effective taxes on dividends from SMEs as a result of incomplete integration between corporate and personal tax systems (Table 2). At one extreme, the full classical system in some OECD countries effectively imposes double taxation on dividends and thus discriminates against the corporate form of organisation (Box 1). Luxembourg, the Netherlands, Switzerland and the United States operate a pure classical system. Austria, Belgium, Hungary, Iceland, Japan, Poland and Sweden rely on a modified classical system, whereby they apply a lower tax rate on dividends to relieve shareholders for part of the tax applied at a corporate level. In other countries, imputation, partial credit or exemption provisions relieve the shareholders for part or all of the tax paid by the company.

Tax systems may encourage debt financing and this discriminates against SMEs which depend on equity financing. In the absence of taxes and transaction costs, the firm will be indifferent to the method in which it finances investment, since the value of the firm is independent of its financing choice - retaining profits, issuing new shares or borrowing (Modigliani and Miller, 1958). However, with the existence of taxes, the value of the firm is generally not independent of the choice of financing method. The present tax system in OECD is not neutral towards corporate financing decisions. The overall standard of deviation - a rough measure of the extent of non-neutrality in corporate financing decision-is above zero in all OECD countries, and is particularly high in France, Japan and the Netherlands, indicating a non-neutral tax system with respect to the choice of corporate financial structure (Figure 3).

In most OECD countries (Australia, Denmark and Finland are exceptions), debt financing is typically preferred over equity financing based on the tax system for several reasons. First, corporate interest payments are tax deductible. Second, double taxation on distributed profits (first at the corporate level and then at the shareholders' level) in some countries depresses the price and discourages the issuance of shares (McKenzie and Thompson, 1996; Lenain and Bartoszuk, 2000). ${ }^{11}$ This form of non-neutrality favours large and established firms, which have easier access to bank loans, while penalising start-ups, which rely on new equity to finance their developments (Lenain and Bartoszuk, 2000). ${ }^{12}$ However, equity financing accounts for a larger share of corporate finance structure than debt, suggesting that there are other considerations than simple tax rules in choosing corporate financing structure. These may include commitment of future cash flows associated with debt; information asymmetry between lenders and borrowers; and disincentives for managers to undertake a high debt load (Auerbach, 2001).

Furthermore, a higher tax burden on distributed profits (subject to both corporate and personal tax) than on retained profits in some OECD tax systems encourages firms to retain their earnings in lieu of distributing them as dividends. Some countries treat retained earnings more favourably than new equity financing by imposing lower tax rates on capital gains (or zero in some cases) at the individual level. This may serve to lock profits within corporations and make it more difficult to reallocate funds from mature, established firms to fast-growing start-ups which have to rely on external sources of finance (OECD, 1991).

11. A lowering of corporate taxes tends to decrease the marginal effective tax rates on new equity and retained earnings while increasing the rate on debt.

12. At a macroeconomic level, debt financing tends to amplify business cycles since corporations are more susceptible to cyclical downturns via shifts in bank lending policies and credit crunches (Dalsgaard and Kawagoe, 2000). 
Table 2. Taxation of dividends, 2000

\begin{tabular}{|c|c|c|c|c|c|c|c|c|c|}
\hline & $\begin{array}{l}\text { Corporate tax } \\
\text { system }^{1}\end{array}$ & $\begin{array}{l}\text { Gross } \\
\text { profits }^{2}\end{array}$ & SME tax rates & Dividend & $\begin{array}{c}\text { Gross- } \\
\text { up }^{3}\end{array}$ & $\begin{array}{l}\text { Top marginal rates of } \\
\text { dividend income }\end{array}$ & $\begin{array}{c}\text { Net } \\
\text { dividend }\end{array}$ & $\begin{array}{l}\text { Dividend } \\
\text { wedge }^{4}\end{array}$ & $\begin{array}{l}\text { Top tax rate for the } \\
\text { self-employed }\end{array}$ \\
\hline Australia & $\mathrm{FI}$ & 151.5 & 34 & 100 & 151.5. & 48.5 & 78.0 & 48.5 & 48.5 \\
\hline Austria & Classical & 151.5 & 34 & 100 & & 25 & 75 & 50.5 & 50 \\
\hline Belgium & Classical & 140.5 & 28.84 & 100 & & 15 & 85 & 39.5 & 61 \\
\hline Canada & $\mathrm{PC}$ & 125.5 & 20.7 & 100 & 125 & 26.5 & 66.9 & 46.6 & 48.5 \\
\hline Czech Rep & PD & 132.4 & 31 & 100 & & 15 & 85 & 35.8 & 32 \\
\hline Denmark & $\mathrm{PC}$ & 147.1 & 32 & 100 & & 40 & 60 & 59.2 & 63.3 \\
\hline Finland & $\mathrm{FI}$ & 140.8 & 29 & 100 & 140.8 & 29 & 100 & 29 & 59.3 \\
\hline France & $\mathrm{FI}$ & 131.2 & 23.8 & 100 & 119.3 & 61.2 & 46.3 & 64.7 & 59 \\
\hline Germany $^{5}$ & $\mathrm{FI}$ & 217.4 & 54 & 100 & 217.4 & 53.8 & 100.4 & 53.8 & 53.8 \\
\hline Greece & ES & 133.3 & 25 & 100 & 133.3 &.. & 100.0 & 25.0 & .. \\
\hline Hungary & Classical & 122.0 & 18 & 100 & & 35 & 65 & 46.7 & $40 / 18^{6}$ \\
\hline Iceland & Classical & 142.9 & 30 & 100 & & 10 & 90 & 37 & 48.64 \\
\hline Ireland & Classical & 114.3 & 12.5 & 100 & & 42 & 58 & 49 & 46 \\
\hline Italy & $\mathrm{FI}$ & 170.4 & 41.3 & 100 & & 12.5 & 87.5 & 48.6 & 46 \\
\hline Japan & Classical & 149.9 & 33.3 & 100 & & 50 & 50 & 66.6 & 50 \\
\hline Korea & $\mathrm{PC}$ & .. &.. & 100 & & 20 & 80 & 35.04 & 44 \\
\hline Luxembourg & Classical & .. & .. & 100 & & 47.2 & .. & 62.8 & 59.2 \\
\hline Mexico & $\mathrm{FI}$ & 102.6 & 2.5 & 100 & 102.6 & 40 & .. & 40.0 & 40 \\
\hline Netherlands & Classical & 142.9 & 30 & 100 & & 60 & 40 & 72 & 60 \\
\hline New Zealand & $\mathrm{FI}$ & 149.3 & 33 & 100 & 149.3 & 33 & 100 & 33 & 39 \\
\hline Norway & $\mathrm{FI}$ & 138.9 & 28 & 100 & 138.9 & 28 & 100 & 28 & 55.3 \\
\hline Poland & Classical & 142.9 & 30 & 100 & & 20 & 80 & 44 & 40 \\
\hline Portugal & $\mathrm{PC}$ &.. & .. & 100 & & 25 & .. & 42.4 & 40 \\
\hline Spain & $\mathrm{PI}$ & 142.9 & 30 & 100 & 140.0 & 48 & 72.8 & 49 & 48 \\
\hline Sweden & Classical & 138.9 & 28 & 100 & & 30 & 70 & 49.6 & 58.1 \\
\hline Switzerland & Classical & 141.6 & 29.4 & 100 & & 43.5 & 56.5 & 60.1 & 47.8 \\
\hline Turkey & PC & 178.9 & 44.1 & 100 & 120 & 49.5 & 60.6 & 66.1 & 49.5 \\
\hline UK & $\mathrm{PI}$ & 111.1 & 10 & 100 & 111.1 & 32.5 & 75 & 32.5 & 40 \\
\hline US & Classical & .. & .. & 100 & & 46.0 & .. & 56.5 & 48.2 \\
\hline
\end{tabular}

Notes: 1. ES, exemption system; FI, full imputation; PC, partial credit for domestic shareholder; PD, partial deduction of dividends paid; and PI, partial imputation.

2. Gross profits: income before corporate taxes which a corporate firm must earn to pay 100 in dividends.

3. Gross-up is the taxable amount of dividends for personal income tax purposes.

4. Total tax wedge is the proportional difference introduced by taxation between gross profits and net dividend. The wedges can also be computed by assuming the same pre-tax or after-tax rates of return.

5. A modified classical system starting 2002 where only half of distributed profits will be included in the shareholder's personal income tax base.

6 . The second rate refers to the capital component of income from self-employment. Additional tax between 20 and 35 per cent is imposed on this component.

Source: National sources, OECD (2001e), Van den Noord and Heady (2001). 
By the very nature of their business, entrepreneurial firms undertake risks and sometimes incur losses. In a system that adheres to taxing economic income, profits and losses should be treated symmetrically so as not to discriminate against risk-taking, i.e. tax profits and provide tax refunds for losses (Shome, 1995). Moreover, the asymmetric treatment of operating losses in the corporate tax system may put start-ups and SMEs at a disadvantage since it may take years before they become profitable. However, it can also be argued that full-loss offsets or rebates may prolong the life of less-efficient and economically obsolete firms and tie up valuable capital. In practice, operating losses are carried backward and forward for a limited number of years in most OECD countries, whereas profits are always taxed without exception. Australia, Austria, Begium, Germany, Ireland, Luxembourg, New Zealand, Sweden and the United Kingdom allow losses to be carried forward indefinitely to be applied to future profits. Some countries (Hungary, Italy, Korea and Spain) which do not have unlimited carry forward provisions, have more generous provisions for start-ups or SMEs. Provisions for carrying backward losses also exist in Canada, France, Germany, Ireland, Japan, the Netherlands, the United Kingdom and the United States (Table 3).

\section{Figure 3. Marginal effective tax wedges in manufacturing by source of financing}

Percentages, 1999

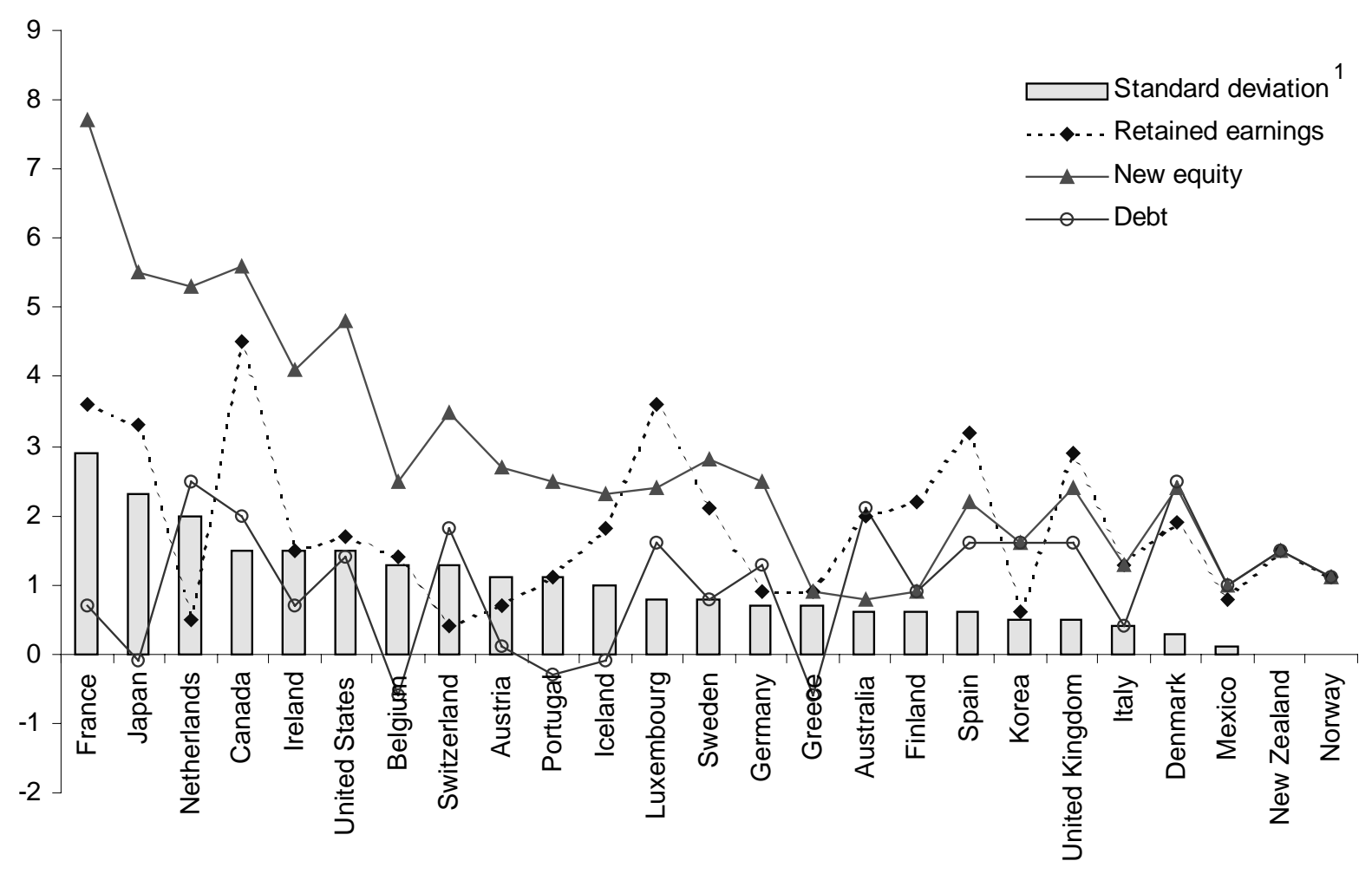

Note: See OECD (1991) for a discussion of the methodology.

1. The standard deviation across financing instruments.

Source: Van den Noord and Heady (2001). 
Table 3. Treatment of operating losses

\begin{tabular}{|c|c|c|c|}
\hline & $\begin{array}{l}\text { Loss carry } \\
\text { forward, } \\
\text { years }\end{array}$ & $\begin{array}{c}\text { Loss carry } \\
\text { backward, } \\
\text { years }\end{array}$ & Special provisions for start-ups and SMEs \\
\hline \multicolumn{4}{|c|}{ Countries with unlimited loss carry forward } \\
\hline Australia & Unlimited & 0 & \\
\hline Austria & Unlimited & 0 & \\
\hline Belgium & Unlimited & 0 & \\
\hline Germany & Unlimited & 1 & \\
\hline Ireland & Unlimited & 1 & \\
\hline Luxembourg & Unlimited & 0 & \\
\hline Netherlands & Unlimited & 3 & \\
\hline New Zealand & Unlimited & 0 & \\
\hline Sweden & Unlimited & 0 & \\
\hline United Kingdom & Unlimited & 1 & \\
\hline \multicolumn{4}{|c|}{ Countries with limited years of loss carry forward } \\
\hline Canada & 7 & 3 & \\
\hline Czech Republic & 7 & 0 & \\
\hline Denmark & 5 & 0 & \\
\hline Finland & 10 & 0 & \\
\hline France & 5 & 3 & \\
\hline Greece & 5 & 0 & \\
\hline Hungary & 5 & 0 & $\begin{array}{l}\text { Losses in the first four years of a start-up may be carried forward } \\
\text { indefinitely. }\end{array}$ \\
\hline Iceland & 8 & 0 & \\
\hline Italy & 5 & 0 & $\begin{array}{l}\text { Losses in the first three years of a start-up may be carried } \\
\text { forward indefinitely. }\end{array}$ \\
\hline Japan & 5 & 1 & \\
\hline Korea & 5 & 0 & SMEs are allowed to carry back losses for one year \\
\hline Mexico & 10 & 0 & \\
\hline Norway & 10 & 0 & $\begin{array}{l}\text { Losses can be carried back two years if a business is } \\
\text { terminated. }\end{array}$ \\
\hline Poland & 5 & 0 & \\
\hline Portugal & 6 & 0 & \\
\hline Spain & 10 & 0 & $\begin{array}{l}\text { For new start-ups, the ten year period begins in their first } \\
\text { profitable year for tax purposes. }\end{array}$ \\
\hline Switzerland & 7 & 0 & \\
\hline Turkey & 5 & 0 & \\
\hline United States & 20 & 2 & \\
\hline
\end{tabular}

\section{Special SME tax provisions}

Many OECD countries have special corporate tax provisions to help SMEs overcome impediments to start-up and growth, but these provisions do not necessarily counter the biases mentioned above. In a recent tax package for small firms for 1999-2003, newly created SMEs in Korea receive a 50\% reduction of income and property tax payments up to five years and are exempt from registration and transaction taxes for two years. A special 20\% tax credit to small firms in the manufacturing sector is also available. Some countries also have special tax provisions available for investments undertaken by SMEs. For instance, SMEs in the Czech Republic can take advantage of a corporate income tax holiday for up to ten years in qualified investments in high-tech manufacturing. Japanese SMEs may take advantage of either an investment tax credit of $7 \%$ or an additional depreciation of $30 \%$ for the acquisition of qualifying machinery or equipment (Ministry of Finance, 2000). Belgium also allows more generous investment deductions for small businesses. Finland, Spain and the United Kingdom allow more generous depreciation allowances for investments made by SMEs. Similarly, the United States permits additional expensing 
allowances to qualified property owned by small businesses under the section 179 expensing. Additional provisions include more generous or targeted $R \& D$ tax incentive programmes for SMEs in Canada, Italy, Japan, Korea, the Netherlands, Norway, and the United Kingdom in 2002. Italy and the United Kingdom have $R \& D$ tax credits in place only for SMEs and are regarded as the most generous in this respect (OECD, 2001a).

A number of countries have special provisions to increase the supply of equity to small firms. Australia, for instance, has special tax rates (15-25\%) for investment companies that provide equity to SMEs. Similarly, Turkey provides corporate tax exemptions to profits derived by risk capital investment funds or companies from transactions involving their operating portfolio. Capital gains realised by individuals in Canada on the disposition of qualified small business corporation shares qualify for a lifetime CAD 500000 capital gains exemption. Moreover, individuals who acquire shares in LabourSponsored Venture Capital Corporations (LSVCCS), which provide capital to SMEs, receive a $15 \%$ federal tax credit on the first CAD 5000 invested per year as well as provincial tax credits. France and the United Kingdom also provide tax incentives for individuals investing in qualified venture funds. The United States allows lower capital gains taxes on shares of small businesses purchased in an initial public offering if those shares are held longer than five years (Mintz and Wilson, 2000). Canada and the United States also allow rollover of capital gains on eligible small business investments.

Some OECD countries have either value-added tax (VAT) exemptions or special VAT provisions for small businesses to lower their compliance costs and the administrative burden. Switzerland's experience indicates that most time and money are spent on VAT compliance compared to other taxes (Carey, Gordon and Thalmann, 1999). Small businesses are exempt from VAT in most OECD countries including Canada, the Czech Republic, France, Germany, Greece, Ireland, Italy, Japan, New Zealand, Poland, Portugal and the United Kingdom (Table 4). Other countries have introduced simplified VAT regimes. These provisions have lowered effective VAT rates below standard rates, particularly in Italy, Mexico and Sweden. However, established thresholds in some countries may be too high according to the optimal threshold estimates calculated by considering a trade-off between compliance costs with efficiency considerations (Keen and Mintz, 2000). Canada also has simplified accounting systems for many other small businesses which are over the small business threshold.

\section{Evaluation of effects}

In general, tax incentives targeted to small firms - including lower corporate tax rates, investment tax credits, VAT exemptions, etc. - should be evaluated to ensure they are addressing market failures and not inducing economic distortions or encouraging tax evasion. Favourable tax treatment of small firms benefits existing firms as well new or technology-based enterprises. A large proportion of established SMEs are not significant creators of new jobs or generators of innovations, and favourable tax treatment of all small firms could be inefficient. Moreover, lower tax rates for SMEs can discourage their growth when small business owners try to keep reported income below certain thresholds to take advantage of the preferential tax treatment of small businesses (Hendricks, Amit and Whistler, 1997). Lower taxes may encourage entrepreneurs to divide businesses into separate components for tax purposes. Small firms may not even benefit from many of these incentives since they need to be profitable before they can make use of tax credits and other measures. These factors should be taken into account in the design of tax provisions for small enterprises. 
Table 4. Value-added taxes, 1998

\begin{tabular}{|c|c|c|c|c|c|}
\hline & \multirow[t]{2}{*}{$\begin{array}{l}\text { Standard } \\
\text { rate }\end{array}$} & \multirow[t]{2}{*}{$\begin{array}{l}\text { Effective } \\
\text { rate }^{1}\end{array}$} & \multirow[t]{2}{*}{$\begin{array}{c}\text { VAT } \\
\text { productivity }^{2}\end{array}$} & \multicolumn{2}{|c|}{ Turnover thresholds for VAT exemption } \\
\hline & & & & Domestic currency & USD PPP \\
\hline Australia & -- & -- & -- & -- & -- \\
\hline Austria & 20.0 & 12.2 & 61.2 & ATS 300000 & 22023 \\
\hline Belgium & 21.0 & 10.3 & 49.0 & BEF 225000 excluding VAT & 5954 \\
\hline Canada & 7.0 & 3.4 & 49.2 & CAD 30000 & 25659 \\
\hline Czech Republic & 22.0 & 10.2 & 46.3 & & \\
\hline Denmark & 25.0 & 14.6 & 58.3 & DRK 20000 & 2332 \\
\hline Finland & 22.0 & 12.9 & 58.5 & FIM 50000 & 8161 \\
\hline France & 20.6 & 10.9 & 53.0 & FRF 100000 excluding VAT & 14917 \\
\hline Germany & 16.0 & 9.4 & 59.0 & DEM 32500 & 16202 \\
\hline Greece & 18.0 & 9.5 & 53.0 & GRD 1.8 million & 7451 \\
\hline Hungary & 25.0 & 12.2 & 49.0 & & \\
\hline Iceland & 24.5 & 13.3 & 54.2 & ISK 200600 & 2404 \\
\hline Ireland & 21.0 & 15.0 & 71.4 & IEP 40000 & 57552 \\
\hline Italy & 20.0 & 8.5 & 42.7 & ITL 5 million & 2987 \\
\hline Japan & 5.0 & 3.7 & 73.7 & JPY 30 million & 182935 \\
\hline Korea & 10.0 & 5.7 & 56.8 & KRW 24 million & 35886 \\
\hline Luxembourg & 15.0 & 8.9 & 59.2 & BEF 400000 & 9633 \\
\hline Mexico & 15.0 & 11.9 & 79.3 & MXN 1000000 & 198037 \\
\hline Netherlands & 17.5 & 10.5 & 60.1 & Net tax payable up to NLD 4150 & 2026 \\
\hline New Zealand ${ }^{3}$ & 12.5 & 13.2 & 105.4 & NZD 30000 & 20250 \\
\hline Norway & 23.0 & 15.0 & 65.3 & NOV 30000 & 3265 \\
\hline Poland & 22.0 & 11.0 & 49.8 & & \\
\hline Portugal & 17.0 & 10.5 & 61.5 & PTE 2 million & 15986 \\
\hline Spain & 16.0 & 8.0 & 49.7 & Individual retailers & -- \\
\hline Sweden & 25.0 & 10.0 & 40.1 & -- & -- \\
\hline Switzerland & 6.5 & 4.9 & 74.9 & CMF 75000 & 37707 \\
\hline Turkey & 15.0 & 8.2 & 54.8 & Varies with activity & -- \\
\hline United Kingdom & 17.5 & 8.8 & 50.1 & GBP 50000 & 75757 \\
\hline United States & -- & -- & -- & -- & -- \\
\hline
\end{tabular}

Notes:

1. VAT revenue divided by its base (i.e. consumption excluding consumption taxes).

2. Effective VAT divided by standard rate.

3. Exceeds $100 \%$ due to differences between the actual VAT base and consumption as measured in national accounts.

Source: National sources, Van den Noord and Heady (2001). 
DSTI/DOC(2002)9

\section{TAXATION OF ENTREPRENEURSHIP}

\section{Estate and inheritance taxes}

Taxes on transfers of wealth or estates may play an important role in entrepreneurship through two channels. First, entrepreneurs typically face liquidity constraints in forming new businesses, and often rely on inheritance as a source of capital. In fact, the size of inheritance has a substantial positive effect on the probability of becoming an entrepreneur (Holtz-Eakin et al., 1994a, 1994b). Therefore, estate taxes which reduce the size of inheritance may lower entrepreneurial activity. Second, high estate-tax liabilities may make it difficult for family businesses to survive the death of their founders (Holtz-Eakin and Marples, 2001). A number of OECD countries including Australia and Canada do not have estate taxes (Figure 4). The United States and the United Kingdom are the only OECD countries to impose a "pure" estate tax. However, the United States is repealing them. Others impose inheritance taxes, where they are based on the size of the inheritance received rather than the total of the estate, and the rate usually varies with the closeness of the relationship between the donor and the recipient. Some of these countries impose capital gains tax at death. For those countries that impose such taxes, the value of the estate where the top rate applies varies significantly. Estate or inheritance taxes appear to be quite high in Japan, the United States and Korea. Some countries, such as France, have introduced special provisions to ease the transmission of small firms among family members, including lowering the tax burden.

\section{Taxes on capital gains}

Capital gains tax may affect the supply of entrepreneurial talent and of capital to start-ups. A substantial part of self-employed income may be reinvested in the firm and subject to capital gains tax (when the business is sold) rather than personal income tax at a later date. Moreover, the demand for entrepreneurs, or alternatively the supply of capital to start-ups, is potentially determined by the relative tax treatment of capital gains that investors in start-ups (in particular, "angel" investors) might be able receive, compared to the after-tax returns they might expect from alternative investments such as receiving dividends by investing in larger firms (Gompers and Lerner, 1999; Poterba, 2001). Furthermore, start-ups are more likely to finance their growth with equity than with retained earnings.

Three general features of capital gains tax can discourage risk-taking activities. First, the absence of deductibility of losses from other sources of income imposes higher effective tax rates on risky investments (Burman, 1999). ${ }^{13}$ Second, most tax systems allow capital losses to be applied against future capital gains, but must be carried forward without interest. The resulting gains are fully shared by governments, while losses, in a present value sense, are only partially shared. This asymmetric treatment of capital gains and losses may discourage risk-taking. Moreover, capital gains taxes may also result in double taxation of retained profits as they may be deferred dividends that are reflected in share values. Lastly, taxes on realised capital gains may create an incentive for asset holders to delay the sale of appreciated assets

13. In Canada, a capital loss on the disposition of the shares can be used to offset other sources of income. 
(referred to as the "lock-in effect"). This may tie up valuable assets which could have been used more productively by small firms.

The tax treatment of capital gains differs widely across OECD countries (Table 5). Some countries such as Belgium and New Zealand do not impose taxes on capital gains at either the corporate or the individual level. A number countries including Greece, Korea, Mexico, the Netherlands, Poland and Switzerland, do not have capital gains tax on shares held by individuals.

\section{Figure 4. Top marginal bequest tax rates, ${ }^{1} 1998$}

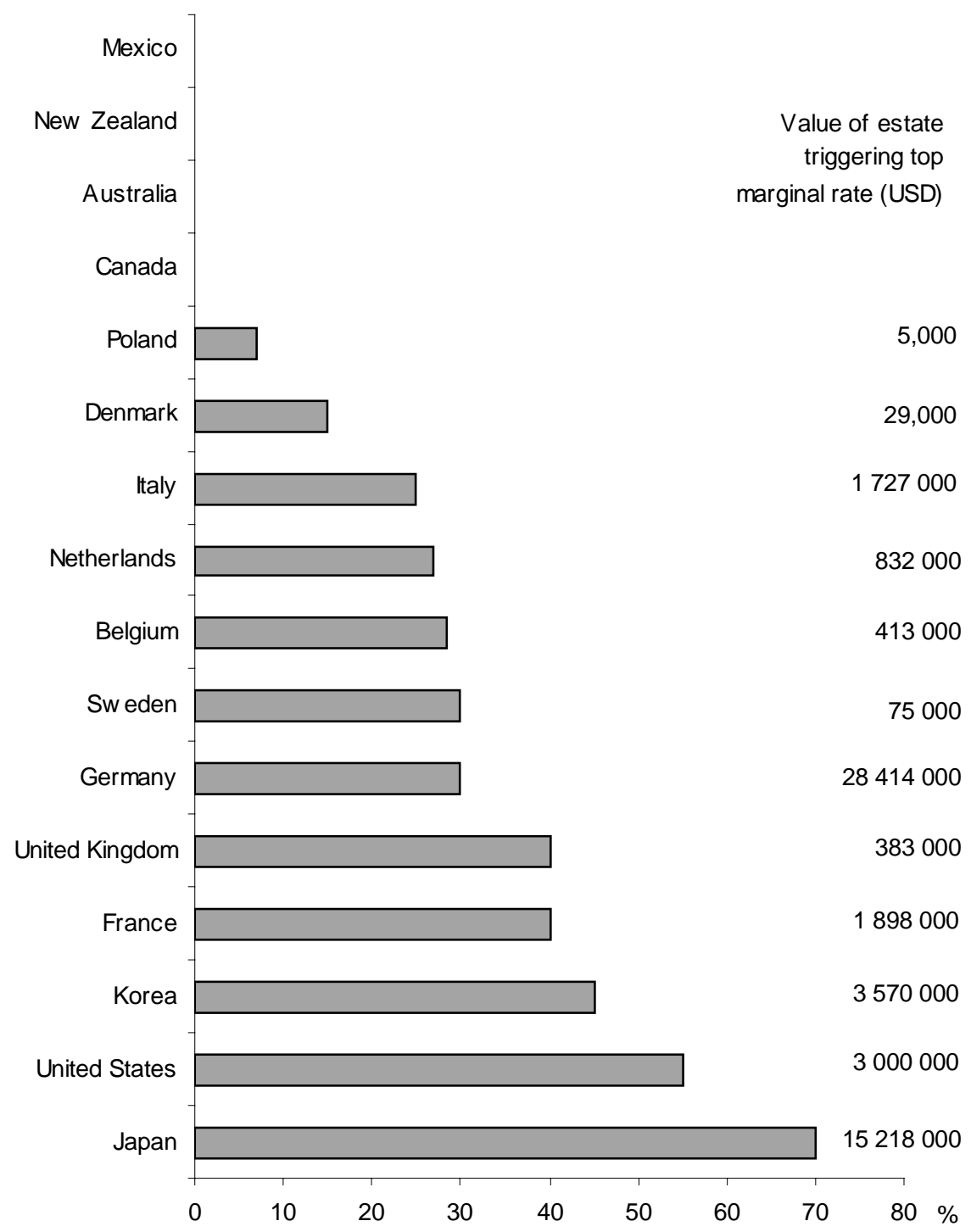

Notes: 1. The rates are for spouses or children. The rates depend on the relationship between the donor and the recipient in Belgium, Czech Republic, Finland, France, Germany, Greece, Italy, the Netherlands and Poland. The rate is zero for a surviving spouse in Denmark, and the United Kingdom. In the United States, transfers between spouses who are U.S. citizens as well as transfers from a non-U.S. citizen to a U.S. citizen spouse, are not subject to estate or gift taxes. A surviving spouse in Sweden is entitled to receive half of the value of the spouse's property, free of inheritance tax. Japan imposes $20 \%$ surtax on transfers to heirs other than the parents and children of the deceased. Korea allows greater exemptions to spouses and children.

2. Some countries such as Canada have a deemed realisation feature where dispositions are deemed to have occurred in the year of death for capital gains tax.

Source: American Council on Capital Formation (1999), Ernst \& Young (2000a). 
Table 5. Taxation of capital gains on shares, 2000 resident taxpayers

\begin{tabular}{llll}
\hline Short-term & Corporate & \multicolumn{2}{c}{ Individual } \\
Long-term & Short-term & Long-term \\
\hline
\end{tabular}

Countries with same capital gains tax rates on corporations and individuals

$\begin{array}{lrrrr}\text { Belgium } & 0 & 0 & 0 & 0 \\ \text { New Zealand } & 0 & 0 & 0 & 0 \\ \text { Ireland } & 20 & 20 & 20 & 20 \\ \text { Norway } & 28 & 28 & 28 & 28 \\ \text { Finland } & 29 & 29 & 29 & 29\end{array}$

Countries with lower tax rates on capital gains by corporations

\begin{tabular}{|c|c|c|c|c|}
\hline Hungary & 18 & 18 & 20 & 20 \\
\hline Canada $^{1,2}$ & 27.9 & 27.9 & 31.3 & 31.3 \\
\hline Sweden & 28 & 28 & 30 & 30 \\
\hline Turkey & 30 & 30 & 50 & 50 \\
\hline
\end{tabular}

Countries with lower tax rates on capital gains by individuals

$\begin{array}{lrrrr}\text { Greece } & 40 & 40 & 0 & 0 \\ \text { Korea } & 28 & 28 & 0 & 0 \\ \text { Mexico } & 35 & 35 & 0 & 0 \\ \text { Netherlands } & 35 & 35 & 0 & 0 \\ \text { Poland } & 30 & 30 & 0 & 0 \\ \text { Iceland } & 30 & 30 & 10 & 10 \\ \text { France } & 33.3 & 33.3 & 26 & 26 \\ \text { Japan } & 41 & 41 & 26 & 26\end{array}$

Countries with lower tax rates on longer-term investments

\begin{tabular}{|c|c|c|c|c|}
\hline Spain & 35 & 35 & 48 & 18 \\
\hline United States $^{3}$ & 35 & 35 & 39.6 & 20 \\
\hline Australia & 34 & 34 & 48.5 & 23.5 \\
\hline United Kingdom & 30 & 30 & 40 & 10 \\
\hline Austria & 34 & 34 & 50 & 0 \\
\hline Czech Republic & 31 & 31 & 32 & 0 \\
\hline Portugal & 32 & 32 & 10 & 0 \\
\hline Germany $^{4}$ & 25 & 25 & 53.8 & 0 \\
\hline Italy & 37 & 27 & 12.5 & 12.5 \\
\hline Denmark & 32 & 32 & 40 & 0 \\
\hline Luxembourg & 30 & 0 & 25 & 0 \\
\hline Switzerland ${ }^{1}$ & 29.4 & 0 & 0 & 0 \\
\hline
\end{tabular}

Notes: Typical capital gains tax rate; may vary across different asset types. Holding periods for long-term assets differ across countries as do other conditions. There is a deferral value to capital gains. That is, the reported rates are lower in present value terms if people postpone the realisation of their gains.

1. Includes both central and sub-central tax rates.

2. The inclusion rate was reduced from three-quarters to two-thirds after February 27, 2000 and was further reduced to one-half effective October 18, 2000. The weighted average inclusion rate of 0.6458 was used. In 2002, the effective combined tax rate on capital gains realised by corporations and individuals would be $19.15 \%$ and $22.7 \%$ respectively.

3. The long term rate on capital gains realised by individuals drops to $18 \%$ in 2001 .

4. Starting 2002, corporate capital gains are exempt from tax if shares have been held for at least one year.

Source: Dalsgaard (2001), Ernst and Young (2001a; 2001b). 
About one-third of OECD countries have capital gains tax rates which decline with the holding period. Spain, the United States, Australia, the United Kingdom, Austria, the Czech Republic, Denmark and Luxembourg have higher short-term rates for assets held by individuals. At the same time, short-term rates are higher for corporate assets in Italy, Luxembourg and Switzerland. The bias favouring longer-term assets are aimed at encouraging managers to make long-term investment decisions, but can reinforce "lockin effects" which may hinder the reallocation of capital towards start-ups and entrepreneurs. A tax free rollover of capital gains can reduce the lock-in effect. For instance, Canada recently introduced a tax free rollover of capital gains on qualified small-business investments when they are reinvested in another small business. Similarly, the United States allows rollover of capital gains from the sale or exchange of small business stock if the proceeds are used to purchase other qualified small business stock within 60 days of the sale of the original stock.

Capital gains and dividends are taxed differently in many OECD countries, thereby creating strong incentives for businesses to structure their organisations in such a way as to minimise tax payments. Moreover, recognising that tax payers attempt to realise earnings in the form of gains (dividends) rather than dividends (gains) if the capital gains tax rate fall below (above) the dividend rate, the tax treatment of both should be addressed together. Various anti-avoidance rules may be needed where the rates diverge.

\section{Taxes on entrepreneurial capital}

In addition to capital gains taxes, a number of other tax features affect entrepreneurial capital and these differ widely by country. The returns to entrepreneurial capital can be affected by taxes on capital investments, which include corporate and personal income taxes on capital income (corporate income taxes and personal income taxes on dividends, interest and capital gains/losses), asset-based taxes and other business taxes on capital inputs. ${ }^{14}$

An attempt is made here to examine the total tax imposed on entrepreneurial capital across nine OECD countries. This includes taxes on capital income at both corporate and personal levels as well as tax provisions such as investment tax credits and tax depreciation allowances. ${ }^{15}$ Using this measure, the marginal effective tax rates (METRs) on capital in small firms have declined in most countries since 1995 (Figure 5) ${ }^{16}$ Ireland now has the most favourable tax regimes (combined corporate and personal taxes) for entrepreneurial capital in small firms, followed by Italy, the United States, and the United Kingdom in both manufacturing and services. Small manufacturing and services firms enjoy a more favourable tax regime than larger counterparts in Canada, France, Italy, Japan, the United Kingdom and the United States. ${ }^{17}$

14. Entrepreneurial capital is the savings provided by entrepreneurs for investment in their projects. We therefore consider the total tax imposed on entrepreneurial income.

15. A detailed methodology is given in Annex A.

16. The reader should be cautioned that METRs are sensitive to various assumptions in their calculations such as economic depreciation, the real interest rate, the inflation rate and the share of different financing sources. This paper assumes that investment in each country used the same financing structure. Moreover, some financing instruments receive a special tax treatment in some countries. For instance, equity funds financed by pension funds are not taxable at the individual level in some countries. These special features are not considered in this paper. These various points imply that the METRs presented in this paper could have been either overestimated or underestimated in some cases.

17. Small firms in services in Ireland face a lower METR compared to large firms. However, in manufacturing, there is no difference in the estimated METR between large and small firms. This is because "a reduction in the tax rate is available on income from the sale of goods manufactured in Ireland giving an effective rate of 10\%". Ernst and Young (2002b), pp. 298-9. 
Figure 5. Marginal effective capital tax rates for domestic investors: the small firm case ${ }^{1,2}$

Manufacturing

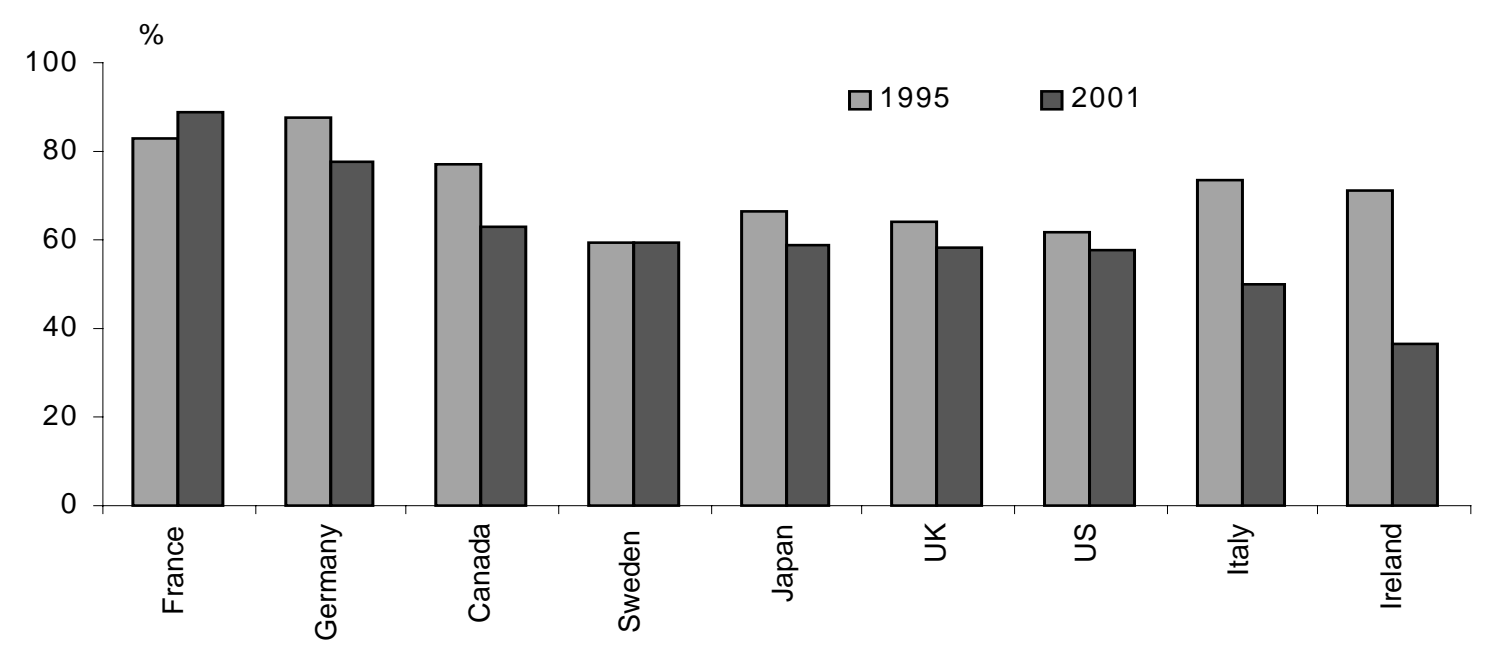

Services

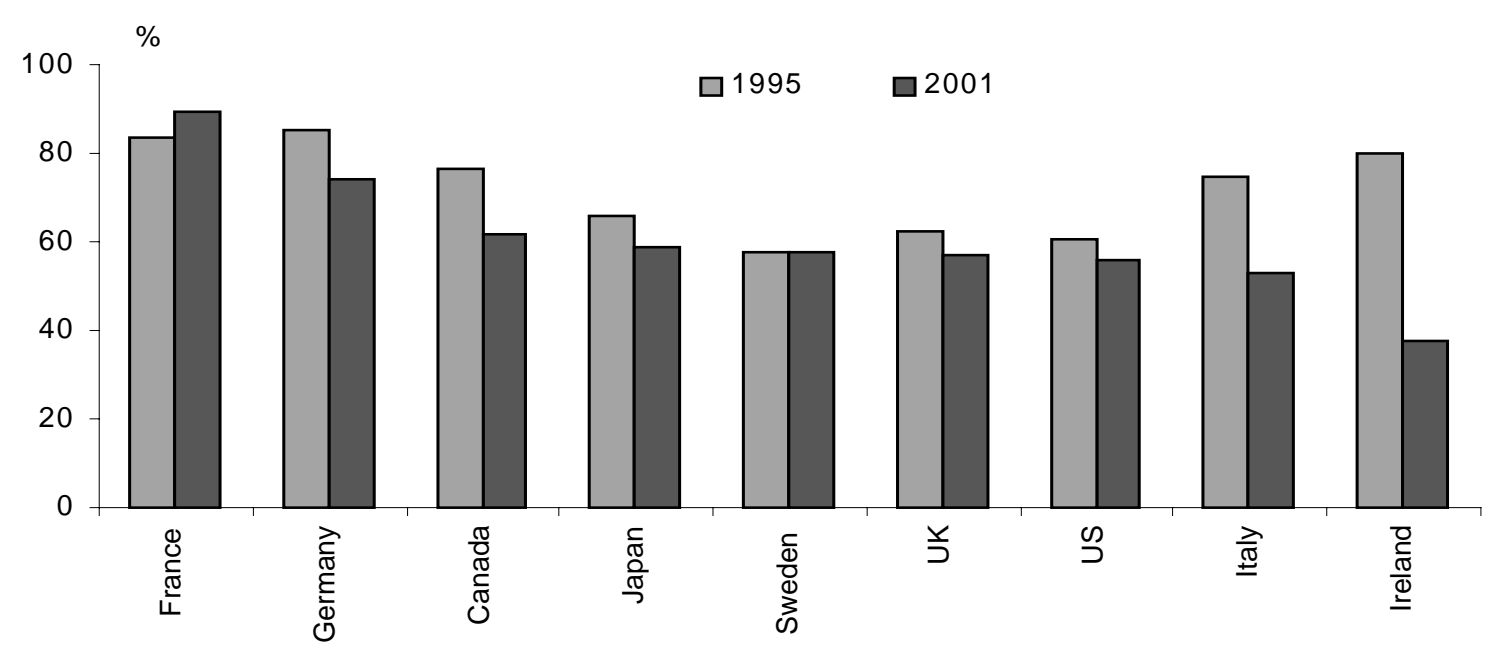

Notes:

1. The effective tax rate is the ratio of the tax wedge (sum of corporate and personal tax wedges) to the before-tax rate of return, where the tax wedge is the difference between before-tax and after-tax rate of return on capital. See Annex A for discussion of the methodology and Annex $B$ for the data used. Based on the assumption that investments are $100 \%$ equity financed. See Table B6 in Annex B for the estimated figures.

2. Definition of small firms is not comparable across countries since it is based on the tax treatment in each country. Source: Authors' calculations. 


\section{STREAMLINING TAX COMPLIANCE}

The tax system imposes costs to businesses and tax-collecting agencies in addition to tax-induced deadweight or efficiency losses. For instance, an estimate for New Zealand indicates administration and compliance costs of around 3\% of GDP (Dalsgaard, 2001). It is also noted that the operating costs (compliance plus administrative costs) of taxation in the United Kingdom were estimated in 1986 to be equivalent to about $1.5 \%$ of GDP (Sandford, 1989).

Compliance costs tend to fall more heavily on SMEs than on larger enterprises. SMEs generally lack internal tax experts; consequently, they often rely more on outside professionals to deal with tax issues. The high cost of outside professionals increases the compliance burden for SMEs (Erard, 1997). Furthermore, economies of scale suggest that the costs of such compliance are higher on a per sales basis for SMEs than for large enterprises. It is also reported that the compliance costs associated with making a single claim on research and development $(R \& D)$ credit in Canada is higher than the value of credit available for most small businesses (Plamondon \& Associates Inc., 1996). In recognition of the relatively higher compliance burden on small firms, some OECD governments are simplifying and streamlining tax procedures for small businesses. For instance, the Canada Customs and Revenue Agency recently introduced a simplified form for claiming expenditures, which small businesses may use instead of the longer form.

Businesses also face the additional cost of complying with tax laws in different levels of governments. Again, this cost is probably more acute for small businesses which may lack additional resources to deal with taxes in different jurisdictions. Thus, governments need to improve tax co-ordination to simplify tax rules and as well as to avoid duplications.

A number of countries have undertaken steps to reduce both administrative and compliance costs. Australia, for instance, introduced a simplified tax system for small businesses to reduce paperwork and compliance burdens. This measure small businesses to determine their income and expenditure on a cash basis (rather than accruals), and provides for assets costing USD 1000 or less to be written off immediately. Italy offers the opportunity to offset tax credits against tax liabilities in a single tax form through the versamento unificato (OECD, 2000). This simplifies and speeds up the refund procedure which is more relevant for SMEs. Portugal also has a simplified tax regime for the determination of profits for small businesses with yearly profits not exceeding PTE 30 million (Bronchi and Gomes-Santos, 2001).

Mexico has set up a simplified tax regime (in terms of less complicated rules and requirements) for small businesses to encourage them to register in the formal sector and lower administrative costs. It also reduced information requirements for keeping accounting records from ten to five years (Dalsgaard, 2000b). The United States now allows small businesses to use the cash method of accounting. SMEs in Spain qualify for special simplified tax regimes (Joumard and Varoudakis, 2000), while New Zealand introduced the "Generic Tax Policy Process" in 1995 to involve the private sector in designing tax policy (Dalsgaard, 2001). This allows government to tap into the technical knowledge of the business community as well as to factor in the concerns of the business community in designing tax policy. 


\section{POLICY ISSUES}

OECD governments can take a number of steps to improve the tax climate for small firms and to encourage entrepreneurship. Governments first need to consider removing tax biases against self-employed individuals and small firms in current tax systems. These include provisions leading to double taxation of entrepreneurial profits, favouring debt over equity financing and giving preferential treatment to longerterm assets. Governments should also evaluate the benefits of reducing progressivity in personal income taxes to encourage entrepreneurs, lowering corporate tax rates on smaller enterprises, enacting more liberal carry-forward provisions, and streamlining tax compliance procedures for SMEs. The following are the main policy recommendations regarding small-firm taxation which governments should review and consider in light of their socio-economic circumstances and overall tax systems:

1. Examine ways to reduce tax biases against equity financing, possibly by improving the integration of personal and corporate income tax systems: ${ }^{18}$

- Double taxation of corporate profits can create distortions in favour of debt over the equity financing, most required by SMEs, while it can also create incentives for individuals to remain self-employed rather than incorporate small firms.

- Double taxation of distributed profits combined with preferential capital gains tax rates can create distortions in favour of retention rather than distribution of earnings, which may limit the reallocation of funds from mature firms to start-ups.

2. Lower progressivity in personal income tax rate schedules: An overly progressive income tax structure penalises successful entrepreneurs and may discourage risk-taking and entrepreneurial investments.

3. Treat losses as symmetrical as possible to gains: Asymmetric treatment between profits and losses in corporate tax systems can discriminate against small firms which may not become profitable for a number of years. This would include more liberal SME provisions for carrying losses forward.

4. Assess the merits of any capital gains tax bias favouring longer-term assets: Favourable treatment of long-term assets can induce a "lock-in effect", which may hinder the reallocation of capital from mature to new firms.

5. Evaluate special SME tax provisions: Tax incentives targeted to small firms and the selfemployed - including lower corporate tax rates and special investment tax credits - should be evaluated to ensure that they are addressing market failures and not inducing economic distortions, encouraging tax evasion or creating disincentives to growth.

18. Some argue that the integration of corporate and personal income tax systems may not be necessary in an open economy as companies can raise capital in international markets. However, there may be a considerable home bias in investment in which case integration of corporate and personal tax does influence investment. One can also argue for integration by focusing on considerations other than capital supply: first, capital gains should be viewed as a reward to entrepreneurship and not necessarily as a return on capital investment; and second, incomplete integration may discourage one form of activity such as stock options against others such as the use of wage and salary compensation (Mintz and Wilson, 2000). 
6. Minimise compliance costs by simplifying tax-related administrative requirements: This may encourage SME growth by lowering the costs of filing tax returns and improving the effectiveness of tax administration, given that SMEs face a heavier compliance burden.

Overall, governments need to ensure that taxes are as neutral as possible so that fundamental economic considerations, not the tax structure, are the guiding principle in investment, organisational and financial decisions (Hubbard, 1993). That is, governments should let the market - and not the tax system - allocate resources. Special tax provisions should be allowed only if there is strong evidence of market failure or equity considerations. In addition, governments need to clearly define their tax systems to avoid any loopholes. More often, the impact of taxation on the economy and entrepreneurship depends not only on the tax system, but also on the tax system's definitional lines and the case with which they can be shifted through tax avoidance activity (Auerbach, 2001). Of course, it should be recognised that the selfemployed and SMEs face size-related obstacles in the economy which may hinder their growth and competitiveness. This should not be ignored and other tools may be used to overcome the disadvantages experienced by SMEs due to their small size. Governments need to consider targeted expenditures or structural reforms that address the roots of these weaknesses, before turning to special tax provisions (Joumard, 2001). 
DSTI/DOC(2002)9

\section{ANNEX A. METHODOLOGY FOR ESTIMATING EFFECTIVE TAX RATE ON CAPITAL}

The method used for estimating marginal effective tax rate (METR) on capital closely follows that outlined in Boadway, Bruce, and Mintz (1984). The effective tax rate is estimated for nine countries, two industries, and large- and small-sized firms. The nine countries are Canada, France, Germany, Ireland, Italy, Japan, Sweden, the United Kingdom and the United States. The two industries are manufacturing and services. The German split-rate system is modelled separately by accounting for differential tax rates on dividends and undistributed earnings (according to the model by which lower tax on dividends translates into a lower combined personal and corporate tax rate on dividends).

\section{Marginal effective tax rate $(t)$ on capital}

As is well known, the effective tax rate is the proportional difference between the gross of tax rate of return on capital $\left(r_{g}\right)$ and the net of tax rate of return on capital. Depending on how the net of tax rate of return on capital is defined, effective tax rate on capital may be differed as effective corporate tax rate $\left(t_{c}\right)$, effective personal tax rate $\left(t_{p}\right)$, and integrated effective tax rate $(t)$. In other words, if the net of tax rate return on capital is estimated as net of (only) corporate tax rate return to capital $\left(r_{n c}\right)$, then the result is effective corporate tax rate $\left(t_{c}\right)$. If the net of tax rate of return to capital is the net of (both) corporate tax and personal income taxes on capital $\left(r_{n}\right)$, then the result is the integrated effective tax rate $(t)$. The difference between these two effective tax rates is the effective personal tax rate on capital $\left(t_{p}\right)$. These effective tax rates may be expressed in the following formulas:

$$
\begin{aligned}
& t=\left(r_{g}-r_{n}\right) / r_{g} \\
& \text { and } t_{c}=\left(r_{g}-r_{n c}\right) / r_{g} \text { and } t_{p}=t-t_{c} \text { or } t_{p}=\left(r_{n c}-r_{n}\right) / r_{g}
\end{aligned}
$$

\section{The real cost of financing $\left(r^{f}\right)$}

The real cost of financing is one of the major components of the gross of tax rate of return to capital. It is defined by:

$$
r^{f}=\beta i(1-U)+(1-\beta) \rho-\pi
$$

with $\beta=$ debt to assets ratio, $i=$ cost of debt, $U=$ the statutory corporate income tax rate, $\rho=$ cost of equity, and $\pi=$ inflation rate. That is, the cost of financing for an investor is the weighted-average cost of financing net of inflation rate.

It should be noted that the cost of equity, $\rho$, is the weighted average cost of retained earnings and dividends. At the market equilibrium condition, $\rho$ may be estimated as $\rho=i(1-m) /(1-e)$, with $m=$ effective personal income tax rate on interest, and $e=$ effective personal income tax rate on equity income. The effective personal income tax rate on equity may be estimated as $e=\theta d+c(1-d)$, with $c$ as the capital gains tax rate, $\theta$ the dividends tax rate, and $d$ the propensity of profit distribution. 


\section{The net-of-tax rate of return on capital $\left(r_{n}\right)$}

The net of corporate tax rate of return on capital is defined by the formula:

$$
r_{n c}=\beta i+(1-\beta) \rho-\pi
$$

and the net of both corporate and personal tax rate of return on capital is defined as:

$$
r_{n}=\beta i(1-m)+(1-\beta) \rho(1-e)-\pi
$$

\section{The gross-of-tax rate of return on capital $\left(r_{g}\right)$}

For depreciable assets including buildings and machineries, the gross-of-tax rate of return on capital $\left(r_{g}\right)$ may be estimated as the following:

$$
r_{g}=(1+t m)\left(r^{f}+\delta\right)(1-k)\left[1-A+\tau(1-U) /\left(\alpha+r^{f}+\pi\right)\right] /(1-U)-\delta
$$

with $\mathrm{tm}=$ tax on transfer of property, $\delta=$ economic depreciation rate, $k=$ investment tax credit rate, $A=$ present tax value of the accumulated capital cost allowance, $\tau=$ capital tax rate, and $\alpha=\operatorname{tax}$ depreciation rate.

For inventory:

$$
r_{g}=\left(r^{f}+U \pi \zeta\right) /(1-U)+\tau
$$

with $\zeta=1$ for FIFO (first-in, first-out) accounting method and 0 for LIFO (last-in, first-out).

For land:

$$
r_{g}=r^{f}(1+t m)\left[1+\tau(1-U) /\left(r^{f}+\pi\right)\right] /(1-U)
$$

\section{Aggregation}

The effective tax rate for a given industry is the proportional difference between the weighted average of the before-tax rate of return by asset type and the after-tax rate of return which is the same across asset type within the industry. That is, the marginal effective tax rate for industry $i\left(t_{i}\right)$ is calculated as follows:

$$
t_{i}=\left(\Sigma_{j} r_{g i j} w_{i j}-r_{n i}\right) / \Sigma_{j} r_{g i j} w_{i j}
$$

where $j$ denotes asset type (i.e. investments in buildings, machinery, inventories, and land), $w_{i j}$ denotes the weight of asset type $j$ in industry $i$. 
DSTI/DOC(2002)9

\section{ANNEX B. TAX PROVISION IN THE NINE COUNTRIES}

This section presents a summary of the tax provisions used for the calculation of effective tax rates. Main sources include Coopers \& Lybrand (1996) and Messere (1998) for 1995, OECD (2001e) for 2000, and International Bureau of Fiscal Documentation (2001), Ernst \& Young (2001a, 2001b) and Arthur Andersen (2001) for 2001.

\section{Taxes at the firm level}

The corporate income tax and related provisions are discussed below. This is followed by a brief review of other taxes at the business level.

\section{The corporate income tax (CIT)}

The CIT rates and other provisions for depreciation and inventory costs are shown in Table B1, combined for national and sub-national governments. There is no sub-national direct tax in France, Ireland, Sweden, and the United Kingdom. The United States has a federal corporate income tax rate, applied at a top rate of $35 \%$. State rates vary by up to $12 \%$ (some states like Texas have no corporate income tax) and the state-level taxes are deductible from the federal corporate income tax. The average federal-state corporate income tax rate is approximately $39.5 \%$.

The most important tax changes undertaken recently include those in Germany, Japan, Italy and Canada, which also have significant sub-national income taxes as explained below.

In Germany, a substantial tax reform was undertaken in the latter part of the 1990s. This reform resulted in a major reduction of corporate income tax rates at the federal level with the elimination of the differences in rates applied to distributed and undistributed earnings. Some preferences were scaled back and a municipal capital tax was eliminated (due to a court decision that challenged its constitutionality). A German municipal trade tax still applies on income (ranging from 13 to $21 \%$ with an average of $18 \%)^{19}$ that is deductible against the federal CIT, and a surcharge on CIT payable was lowered in 1998 from $7.5 \%$ to $5.5 \%$. The municipal base is similar to the federal base, although only one-half of interest expense is deductible from income. Although the CIT rate at the national level was reduced from $40 \%$ to $25 \%$ in 2001, the aggregated CIT still amounts to over 39\%, once municipal tax and surtaxes are included.

In Japan, tax reforms have led to reductions in CIT rates from about $52 \%$ to $43 \%$ by 2000 . The Japanese corporate tax includes the central government tax, prefecture and corporate inhabitant tax. The central rate has been reduced from $37.5 \%$ to $30 \%$ (top rate) and from $28 \%$ to $22 \%$ (smaller companies with capitalisation less than JPY 100 million and income JPY 8 million or less). A progressive corporate enterprise tax at prefecture level is also levied at various rates with the top rates applied to taxable income above JPY 3.5 million. This tax is deductible for CIT purposes. The top rate was reduced from $12.6 \%$ in

19. It should be noted that under the municipal trade tax, taxable income is subject to certain adjustments, such as a $50 \%$ add-back of interest on long-term debts. 
1995 to $9.6 \%$ in 2000 , and then increased to $10.8 \%$ in 2001 . There is also the corporate inhabitant surtax on corporate income tax payable to both prefectures and municipalities and levied at maximum rates of $6 \%$ and $14.7 \%$, respectively. As a result, the combined corporate income tax rate is about $43 \%$ and $34 \%$, respectively, for large and small firms in 2001, which marks a significant drop from 52\% and $42 \%$, respectively, in 1995.

Italy's corporate income tax underwent substantial reform in 1998. The central government corporate income tax was levied on corporate profits at a rate of $37 \%$. The new "dual income tax" applies at a rate of $36 \%$ in general, but is reduced to $19 \%$ of qualifying income (qualifying income is defined as $7 \%$ of increases in net equity multiplied by a factor of 1.2 in 2000 and 1.4 in subsequent years). The average rate cannot be less than $27 \%$ (an exception applies to the first three years of a company newly listed on a stock exchange). Substantial reforms also took place with respect to local taxes. Unlike Germany and Japan, Italy does not permit local income taxes to be deductible from the central government corporate income tax. The local income tax (ILOR) in 1995 was applied on profits at the rate of 16.2\%. In 1998, a new local tax (IRAP) was levied on business value-added base, defined as revenues net of non-capital purchases; it varies (since the reduction) according to the business. No deduction for interest and wage costs is permitted. Since 2000 , the rate is $4.25 \%$ on manufacturing and $8.5 \%$ for commercial activities. ${ }^{20}$ Finance and insurance are taxed at different rates. With the new local regimes, an older payroll tax and capital tax was eliminated.

Canada has both national and sub-national corporate income taxes, the latter being non-deductible against federal tax. Since 2000, the federal and provincial governments have put in place planned reductions in corporate income tax rates by 2005 . The federal general rate is reduced on active business income by one percentage point in 2001, followed by two percentage points in each of the subsequent three years. The federal rate will therefore decline by seven percentage points in total from $29.12 \%$ to $22.12 \%$ (including the surtax). A special lower rate applied to manufacturing and processing will disappear and a new regime will likely be introduced for resource companies. At the provincial level, Ontario is reducing rates from $15.5 \%$ to $8 \%$, with the distinction between manufacturing and non-manufacturing profits also disappearing in Ontario (Quebec also has a tax rate of $9 \%$ applied on manufacturing and nonmanufacturing profits). Alberta is reducing its general rate to $11.5 \%$ by 2005 . British Columbia and New Brunswick have also announced a three-point and four percentage point reduction in rates. The average provincial rate is therefore falling from about $14 \%$ to $10 \%$ by 2005 , although some other provinces may also follow with lower rates.

\section{Small business}

Among the nine countries under analysis, six provide special treatment for small businesses under the CIT. As Table B1 shows, the gap in the statutory CIT rate applicable to small business compared to the general rate ranges from 7.5 percentage points (Ireland) to over 20 percentage points (Canada). In the Canadian case, this gap will be shrinking through 2005 mainly due to the reduction in the general CIT rate.

In the United States, there are two types of preferential tax treatment towards small business. One is the progressive federal CIT, in which tax rates increase up to 35\% depending on the level of income earned by the corporation. ${ }^{21}$ More important, perhaps, is the special tax treatment for firms with sub-chapter-S

20. It should be noted that, under the local income tax, certain deductions (including labour costs and interest expenses, except for banks and holding companies) are not allowed.

21. There are eight different taxable income brackets corresponding to different corporate tax rates with two phase out regimes. The lower rate for small firms shown in our tables is the one combining the $15 \%$ federal CIT rate and the average state CIT rate of $6.9 \%$ and corresponding to the first USD 50000 of taxable income. 
corporate status. ${ }^{22}$ Under this special treatment, corporate income and tax preferences are passed on to the shareholders on a pro-rate basis regardless of the actual distribution. As a result, the net corporate income is taxed at personal income tax rate and payable by the shareholders.

The two countries that do not levy different tax rates, according to firm size or type of business activity are Germany and Sweden. However, both these countries have other unique features in their CIT provisions. As mentioned, Germany had taxed distributed profits at a CIT rate lower than that applied on retained earnings until the year 2000. This differentiated treatment was related to dividend taxation at the personal level, to be further discussed below. In Sweden, a company could deduct a reserve equal to $25 \%$ of the taxable income for each financial year. Each year's reserve must be added to taxable income no later than six years after the year of the deduction. This feature effectively reduces the statutory CIT rate to a level lower than $28 \%$ depending on the prevailing discount rate. ${ }^{23}$

\section{Tax depreciation allowances}

Table B1 also provides depreciation allowance under the corporate income taxes by country. ${ }^{24}$ Considering that a given depreciation rate based on the declining balance method is roughly equivalent to one-and-half times the rate under the straight-line method, the tax depreciation allowances appear to be within a similar range, with Japan and Italy at the low end for machinery, and Canada at the low end for buildings. It also appears that the United States provides the most generous deduction for investments in machinery and equipment, while Canada is comparable for the manufacturing industry. The United Kingdom provides a $40 \%$ first-year allowance for small business' investments in plant and machinery since 1998. Ireland provides a number of allowances for targeted investments.

\section{Investment tax credits}

Many countries have dispensed with investment tax credits. In Canada, investment tax credits are available for qualifying investments in the Atlantic region and research and development. The United States provides an investment tax credit for incremental research and development. Japan provides a tax credit for incremental research and development expenditures as well as $7 \%$ credit (or $20 \%$ if corporate tax, whichever is less), for small business investments in qualifying plant and machinery.

22. The sub-chapter S-corporation is a hybrid business entity that combines the flexibility of the partnership format with the advantages of operating in a corporate form.

23. Since the current taxable income is reduced by $25 \%$, which may be added back to the taxable income (no later than) six years later, the effective statutory CIT rate may be estimated as the sum of $28 \% *(1-25 \%)+$ $7 \% /(1+\mathrm{R})$, with $\mathrm{R}$ as the prevailing discount rate.

24. Tax depreciation allowances for Canada are calculated precisely using estimates based on the capital weights by industry. In the United States, the modified accelerated cost recovery system (MACRS) adopts a mixture of straight-line rate and declining-balance rate to accelerate the tax depreciation. To facilitate the calculation, we estimate the equivalent declining-balance rates for buildings and machinery based on the MACRS and using the Canadian capital weights. For other countries, we used Canadian weights to estimate approximate tax depreciation rates. 
Table B1. Corporate tax provisions, 1995, 2000 and 2001

\begin{tabular}{|c|c|c|c|c|c|c|c|c|c|}
\hline & Canada & France & Germany & Italy & Japan & UK & US & \multicolumn{2}{|c|}{ Ireland Sweden } \\
\hline \multicolumn{10}{|c|}{ Large CIT } \\
\hline 1995 & $34.8-43.2$ & 36.7 & $44.4-57.7$ & 53.2 & 51.6 & 33.0 & 39.5 & $10.0-38.0$ & 28.0 \\
\hline 2000 & $34.7-43.4$ & 41.7 & $44.4-54.0$ & $41.3-45.5$ & 40.9 & 30.0 & 39.5 & $10.0-24.0$ & 28.0 \\
\hline 2001 & $34.0-41.4$ & 36.4 & 39.6 & $40.3-44.5$ & 42.6 & 30.0 & 39.5 & $10.0-20.0$ & 28.0 \\
\hline \multicolumn{10}{|c|}{ Small CIT } \\
\hline 1995 & 21.3 & n.a. & n.a. & n.a. & 41.7 & 25.0 & $20.9-39.5$ & n.a. & n.a. \\
\hline 2000 & 20.7 & 23.8 & n.a. & n.a. & 33.3 & 20.0 & 20.9-39.6 & 12.5 & n.a. \\
\hline 2001 & 19.9 & 25.0 & n.a. & n.a. & 34.2 & 20.0 & $20.9-39.7$ & 12.5 & n.a. \\
\hline
\end{tabular}

Tax depreciation rate ${ }^{1}$

Manufacturing

\begin{tabular}{|c|c|c|c|c|c|c|c|c|}
\hline Buildings & 4.3 DB & $5.0 \mathrm{SL}$ & $4.0 \mathrm{SL}$ & $3.0 \mathrm{SL}$ & $4.0 \mathrm{SL}$ & $4.0 \mathrm{SL}$ & $5.4 \mathrm{DB}$ & $4.0 \mathrm{SL} \quad 4.0 \mathrm{SL}$ \\
\hline Machinery & $26.2 \mathrm{DB}$ & $15.0 \mathrm{SL}$ & $15.0 \mathrm{SL}$ & $13.0 \mathrm{SL}$ & $10.0 \mathrm{SL}$ & $25.0 \mathrm{DB}^{2}$ & $39.0 \mathrm{DB}$ & 15.0-20.0 $0^{3} \mathrm{SL} 30.0 \mathrm{DB}$ \\
\hline \multicolumn{9}{|l|}{ Services } \\
\hline ildings & 4.3 DB & $5.0 \mathrm{SL}$ & $4.0 \mathrm{SL}$ & $3.0 \mathrm{SL}$ & $4.0 \mathrm{SL}$ & $4.0 \mathrm{SL}$ & $5.4 \mathrm{DB}$ & $4.0 \mathrm{SL}$ \\
\hline chinery & $25.6 \mathrm{DB}$ & $15.0 \mathrm{SL}$ & $15.0 \mathrm{SL}$ & $13.0 \mathrm{SL}$ & $10.0 \mathrm{SL}$ & $25.0 \mathrm{DB}^{2}$ & $41.1 \mathrm{DB}$ & $15.0-20.0^{3}$ SL 30. \\
\hline
\end{tabular}

Business tax

$\begin{array}{lllllll}\text { No } & 3.5-4 & \text { No } & \text { No No No No }\end{array}$

Capital tax

$\begin{array}{lllllll}0.34 & \text { No } & 0.75 & \text { No } & \text { No } & \text { No } & \text { No }\end{array}$

Property transfer tax

$\begin{array}{llllllll}\text { No } & 6.4 & 2.0 & 3.8 & 1.5 & 1 & \text { No } & \text { No }\end{array}$

Inventory accounting

FIFO FIFO

Notes:

1. $\mathrm{SL}=$ Straight-line depreciation rate $\mathrm{DB}=$ Declining-balance depreciation rate.

FIFO = first-in first-out; LIFO = last-in, first-out.

2. The United Kingdom provides $40 \%$ first year allowance for small business' investment in machinery and equipment.

3. The depreciation rate for machinery in Ireland is 15\% prior to 2001 and 20\% since 2001.

Source: Arthur Andersen (2001), Coopers \& Lybrand (1996), Ernst \& Young (2001a, 2001b), International Bureau of Fiscal Documentation (2001), Messere (1998), OECD (2001e). 


\section{Other taxes on capital payable at firm level}

Business taxes: France imposes a business tax on all taxpayers carrying on business. The taxable base is the "annual rental" or "deemed rental" value of the company's tangible fixed assets plus $18 \%$ of gross salaries and benefits in kind. The rate varies according to location but minimum amounts apply and the base tax may also be limited to a percentage of turnover. The maximum percentages ranged from $3.5 \%$ to 4\% depending on the turnover (from under FRF 140 million to above FRF 500 million).

Capital taxes: Canada levies the highest capital taxes. In Canada, half the provincial governments (British Columbia, Manitoba, Ontario, Quebec and Saskatchewan) impose a capital tax on non-financial firms, with rates ranging from $0.225 \%$ to $0.6 \%$ of paid-up capital. British Columbia has since announced that it would abolish its capital tax by 2002 . Ontario has also announced its intention to eliminate its capital tax, however, no specific time frame for its elimination has been provided. In Germany, there was a tax of $0.45 \%(0.6 \%$ on $75 \%$ of net assets plus one-half of debt over DEM 500000$)$ that was not deductible for income tax purpose. This tax was abolished in January 1997. In Italy, there was also a $0.75 \%$ tax on assets net of liabilities before 1998 .

Property transfer taxes: In Italy, there is a registration tax on the transfer price of land and buildings, with tax rates ranging from $3 \%$ to $8 \%$. France levies a registration duty on the transfer of properties. The rate on the disposal of buildings used by companies that set up or acquire plants is $6.4 \%$. In Japan, an acquisition tax of $3 \%$ or $4 \%$ of the taxable value of property is imposed on real estate at the time of acquisition. The United States and Canada also impose land transfer taxes at the sub-national level but these are not included in our analysis.

\section{Taxes on capital income at personal level}

Many of the countries included in this survey have changed the tax treatment of dividends and capital gains in the past few years. In Europe, in the late 1990's, several countries (Germany, Ireland and the United Kingdom) dismantled corporate imputation systems for dividends that ensured that corporate tax was paid on dividends eligible for a tax credit given to taxpayers as an offset for corporate tax applied prior to the distribution of earnings. Countries, like the United Kingdom, Japan, Germany and Canada now provide a partial integration system whereby personal taxes on dividends and capital gains are reduced so that income, at the corporate and personal level, bears tax more similar to other sources of income. Sweden, the United States and Ireland (since 1999) do not integrate personal and corporate taxes.

Table B2 provides a summary of taxes on capital income at personal level. Capital income includes interest income, dividends and (non-speculative) capital gains from financial investment. Similar to the trend in corporate income taxation, taxes on capital income have been generally reduced. The exception is France, where taxes rose noticeably in 2000 compared to1995 but show signs of reduction in 2001.

As Table B2 shows, Sweden uniformly taxes all types of investment income as ordinary income. Among the other countries, except for Italy and Japan, interest is generally taxed as ordinary income and hence subject to a higher tax rate compared to dividends and capital gains. In Italy, a withholding tax on interest income is final for individuals (but an advance payment for firms); the tax rate is lower on interest on government bond and higher on other interest incomes. In Japan, a flat tax of $20 \%$ has long been applied to interest income.

In terms of dividends, as stated above, Sweden, Ireland (since 1999) and the United States tax dividends as ordinary income with no credit given for CIT paid at the firm level. Italy taxes dividends separately from ordinary income and at a single tax rate, which is obviously lower than the top taxpayer's 
marginal rate. Other countries adopt an imputation system that gives a tax credit to individual recipients to, fully or partially, offset CIT paid at the firm level. Among these countries, all but Japan and Ireland use the gross-up method in dividend tax computations. The tax rates shown in Table $2 \mathrm{~A}$ are our estimate of the actual amount of dividends received by individuals. ${ }^{25}$

Finally, except in Germany and the United Kingdom, capital gains are generally taxed lower than dividends. In Canada and Germany tax capital gains are taxed only partially at the ordinary PIT rate. It should be noted that the tax rates shown in our table are applicable to long-term, non-speculative capital gains from portfolio investment although the length of "long term" may vary across countries. Furthermore, the exempt amount of capital gains also varies across countries.

It should be borne in mind that the tax rates on capital income shown in our tables are based on the assumption that all individual savers are taxed at the highest income bracket (interest) and have taken full advantage of exempt amount under taxes on capital gains. As a result, applying these rates estimate may entail an upward bias in our estimates of the effective tax rate.

Table B2. Personal income tax on investment income

\begin{tabular}{|c|c|c|c|c|c|c|c|c|c|}
\hline & Canada & France & Germany $^{1}$ & Italy & Japan & UK & US $^{2}$ & Ireland & Sweden \\
\hline \multicolumn{10}{|c|}{ Interest } \\
\hline 1995 & 52.3 & 56.8 & 53.0 & $12.5-30$ & 20.0 & 40.0 & 43.7 & 48.0 & 30.0 \\
\hline 2000 & 48.5 & 61.2 & 53.8 & $12.5-27.0$ & 20.0 & 40.0 & 43.7 & 24.0 & 30.0 \\
\hline 2001 & 46.0 & 60.1 & 53.8 & $12.5-27.0$ & 20.0 & 40.0 & 43.7 & 24.0 & 30.0 \\
\hline \multicolumn{10}{|c|}{ Dividends } \\
\hline 1995 & 36.1 & 35.2 & 10.5 & 23.4 & 30.0 & 20.0 & 43.7 & 48.0 & 30.0 \\
\hline 2000 & 33.1 & 41.8 & 10.3 & 12.5 & 30.0 & 22.5 & 43.7 & 22.0 & 30.0 \\
\hline 2001 & 31.3 & 40.2 & 10.3 & 12.5 & 30.0 & 25.0 & 43.7 & 20.0 & 30.0 \\
\hline \multicolumn{10}{|c|}{ Capital gains } \\
\hline 1995 & 39.2 & 19.4 & 26.5 & 25.0 & 34.0 & 40.0 & 32.9 & 40.0 & 30.0 \\
\hline 2000 & 31.3 & 26.0 & 26.9 & 12.5 & 26.0 & 10.0 & 25.5 & 20.0 & 30.0 \\
\hline 2001 & 23.0 & 20.8 & 26.9 & 12.5 & 26.0 & 10.0 & 23.6 & 20.0 & 30.0 \\
\hline
\end{tabular}

1. Germany makes a distinction between taxing capital gains on portfolio investment and participatory shares in closely-held companies. $50 \%$ of PIT rate is used to average out the tax rate on capital gains from the portfolio vs. closely-held capital investments.

2. The federal capital gains tax rate is $28 \%, 20 \%$ and $18 \%$ respectively for 1995,2000 and 2001 . The average state rate is $6.87 \%$, which is deductible from the federal rate.

Source: Arthur Andersen (2001), Coopers \& Lybrand (1996), Ernst \& Young (2001a, 2001b), International Bureau of Fiscal Documentation (2001), Messere (1998), OECD (2001e).

25. The typical formula for this estimate is the tax rate, which equals (PIT rate on dividends - tax credit rate)* gross-up amount/100. In the Sweden and US cases, both tax credit and gross-up amount are zero; for Japan and Ireland, the gross-up amount is zero. For Italy, such an estimate is not necessary since the withholding tax on dividends is final. 
DSTI/DOC(2002)9

\section{Effective tax rates on capital}

Tables B3 and B4 provide our estimates of the marginal effective tax rates on entrepreneurial capital in large firms and small firms respectively where entrepreneurs are assumed to finance $40 \%$ of their investments by debt and $60 \%$ by equity (of which $24 \%$ through dividends and $36 \%$ through capital gains). They are based on the assumption that assets are held for an average holding period of ten years. The interest rate used for our calculation is the average government long-term bond rates among nine countries, which is $6.4 \%$. The inflation rate is also the simple average across countries, which is $2.4 \%$ based on consumer price index. Both parameters are for year 2000 and obtained from the IMF database (International Financial Statistics). These estimates are used for all the three years (1995, 2000, and 2001) for comparisons. Tables B4 and B5 also present estimates of METRs, but based on the assumption that entrepreneurs finance investments entirely through equity (which is further split into $40 \%$ dividends and $60 \%$ capital gains for the purpose of tax structure).

The effective corporate and personal tax rates are expressed as a percentage of the gross rate of return to capital ("gross" implying both corporate and personal tax). Each component - effective corporate and personal tax rates - are calculated as a proportion of this gross rate of return of capital so that the numbers are cumulative. Thus, for example, suppose a project earns a $20 \%$ rate of return on capital. If the effective corporate tax rate is $30 \%$, the rate of return, after payment of corporate taxes, is $14 \%$. Further, if the effective personal tax is $40 \%$ (which is $40 \%$ of the $20 \%$ rate of return), the rate of return after the payment of corporate and personal taxes is $6 \%(14 \%-8 \%)$.

To estimate the effective tax rate, it is important to invoke some sort of capital-market equilibrium. Our model assumes a global capital-market equilibrium in debt markets so that the interest rate on bonds issued by firms is the same across all countries. However, consistent with most empirical work, equity markets are closed, so that the rate of return on equity will vary across countries. The rate of return on equity is determined by owners arbitraging between bond and equity assets so that after-personal tax rates of return are the same on both assets. Thus, in equilibrium, the rate of return on equity after payment of dividend and capital gains taxes is equal to the interest rate on bonds, net of personal tax payments on bonds. Note that in our model, we assume that there is an optimal dividend policy to attract investors to finance equity (that would arise in signalling models) - the cost of equity is therefore affected by both dividend and capital gains tax rates.

As shown in Tables B3, B4, B5 and B6 the effective tax rates on capital investment are generally lower in 2001 compared to 1995, except for France and Sweden. As illustrated in Table B2, there has been no change in Sweden, but income tax rates (particularly on the personal income taxes) in France are higher in 2000 compared to 1995.

With 100\% equity financing (Tables B5 and B6), corporate effective tax rates become significantly higher than the debt-equity financing (Tables B3 and B4), but the overall effective tax rates do not all change in the same direction. This is because the (reductive) impact of the non-existence of interest income taxable at the personal level on the overall effective tax rates may, or may not, overweigh the (incremental) impact of the non-existence of tax-deductible interest cost at the firm level on the corporate effective tax rates. It is also noteworthy that PIT rate on interest is generally higher than that on dividends and capital gains except for Japan and Sweden. 
Specifically, the following can be concluded:

- The most favourable tax regimes for entrepreneurial capital in a larger firm case in 2001 are found in Ireland, followed by Italy, Sweden and Japan. France and Germany have the highest combined corporate and personal tax rates on entrepreneurial capital, largely reflecting higher personal income tax rates in France and relatively higher corporate income tax rates in Germany.

- Entrepreneurial capital invested at the small-business level seems to face the lowest level of taxation in Ireland and Italy in 2001. Japan, Sweden, the United Kingdom and United States face higher levels of taxation, with France and German entrepreneurial capital facing the highest level of tax.

- Combined corporate and personal effective tax rates in most countries have declined since 1995.

- For most countries, effective personal tax rates in the equity financed case tend to be lower than those in the debt-equity financed case.

- Some countries that offer favourable capital gains tax regimes (such the United States and Ireland) lose some advantage by taxing dividends more heavily and by not integrating corporate and personal taxes. 
Table B3. Marginal effective tax rate for domestic investors, 1995, 2000 and 2001

The large-firm case, $60 \%$ equity financed and $40 \%$ debt financed

\begin{tabular}{|c|c|c|c|c|c|c|c|c|c|}
\hline & Canada & France & Germany & Italy & Japan & UK & US & Ireland & Sweden \\
\hline \multicolumn{10}{|c|}{ Manufacturing } \\
\hline \multicolumn{10}{|l|}{1995} \\
\hline Corporate & 28.3 & 14.6 & 54.3 & 35.7 & 34.6 & 21.9 & 23.1 & 4.8 & 16.0 \\
\hline Individual & 54.3 & 70.3 & 32.9 & 26.2 & 24.6 & 43.1 & 48.6 & 67.7 & 37.2 \\
\hline Combined & 82.6 & 84.8 & 87.2 & 62.0 & 59.2 & 65.0 & 71.7 & 72.5 & 53.2 \\
\hline \multicolumn{10}{|l|}{2000} \\
\hline Corporate & 28.2 & 14.3 & 39.2 & 22.6 & 24.7 & 19.3 & 22.5 & 5.1 & 16.0 \\
\hline Individual & 48.7 & 80.6 & 44.9 & 23.7 & 26.1 & 42.9 & 47.6 & 31.5 & 37.2 \\
\hline Combined & 76.9 & 94.8 & 84.1 & 46.3 & 50.8 & 62.2 & 70.1 & 36.6 & 53.2 \\
\hline \multicolumn{10}{|l|}{2001} \\
\hline Corporate & 27.7 & 13.6 & 28.4 & 22.0 & 26.0 & 19.4 & 22.3 & 4.2 & 16.0 \\
\hline Individual & 44.7 & 78.5 & 52.8 & 23.9 & 25.6 & 43.3 & 47.4 & 31.2 & 37.2 \\
\hline Combined & 72.4 & 92.1 & 81.3 & 45.9 & 51.7 & 62.7 & 69.7 & 35.4 & 53.2 \\
\hline \multicolumn{10}{|c|}{ Services } \\
\hline \multicolumn{10}{|l|}{1995} \\
\hline Corporate & 29.4 & 16.2 & 43.8 & 38.7 & 33.6 & 16.1 & 22.0 & 17.3 & 12.2 \\
\hline Individual & 53.4 & 68.9 & 40.4 & 25.0 & 25.0 & 46.3 & 49.3 & 58.8 & 38.8 \\
\hline Combined & 82.9 & 85.1 & 84.3 & 63.7 & 58.6 & 62.4 & 71.3 & 76.1 & 51.0 \\
\hline \multicolumn{10}{|l|}{2000} \\
\hline Corporate & 29.5 & 15.8 & 27.5 & 29.6 & 24.0 & 13.6 & 21.2 & 10.5 & 12.2 \\
\hline Individual & 47.8 & 79.2 & 53.5 & 21.5 & 26.3 & 45.9 & 48.4 & 29.7 & 38.8 \\
\hline Combined & 77.3 & 94.9 & 81.0 & 51.2 & 50.4 & 59.6 & 69.6 & 40.2 & 51.0 \\
\hline \multicolumn{10}{|l|}{2001} \\
\hline Corporate & 28.1 & 15.2 & 19.5 & 29.0 & 25.3 & 13.8 & 21.0 & 7.5 & 12.2 \\
\hline Individual & 44.4 & 77.0 & 59.4 & 21.7 & 25.9 & 46.3 & 48.2 & 30.1 & 38.8 \\
\hline Combined & 72.5 & 92.2 & 78.9 & 50.7 & 51.2 & 60.1 & 69.2 & 37.6 & 51.0 \\
\hline
\end{tabular}


Table B4. Marginal effective tax rate for domestic investors, 1995, 2000 and 2001

The small firm case, $60 \%$ equity financed and $40 \%$ debt financed

\begin{tabular}{|c|c|c|c|c|c|c|c|c|c|}
\hline & Canada & France & Germany & Italy & Japan & UK & US & Ireland & Sweden \\
\hline \multicolumn{10}{|c|}{ Manufacturing } \\
\hline \multicolumn{10}{|l|}{1995} \\
\hline Corporate & 13.0 & 14.6 & 54.3 & 35.7 & 26.1 & 15.9 & 8.8 & 4.8 & 16.0 \\
\hline Individual & 65.9 & 70.3 & 32.9 & 26.2 & 27.8 & 46.4 & 57.6 & 67.7 & 37.2 \\
\hline Combined & 78.9 & 84.8 & 87.2 & 62.0 & 53.9 & 62.3 & 66.4 & 72.5 & 53.2 \\
\hline \multicolumn{10}{|l|}{2000} \\
\hline Corporate & 12.5 & 13.8 & 39.2 & 20.0 & 19.0 & 11.0 & 9.1 & 5.1 & 16.0 \\
\hline Individual & 59.3 & 81.0 & 44.9 & 24.5 & 28.1 & 47.3 & 55.8 & 31.5 & 37.2 \\
\hline Combined & 71.9 & 94.8 & 84.1 & 44.5 & 47.1 & 58.3 & 64.9 & 36.6 & 53.2 \\
\hline \multicolumn{10}{|l|}{2001} \\
\hline Corporate & 12.0 & 13.7 & 28.4 & 19.4 & 19.6 & 11.1 & 9.2 & 4.2 & 16.0 \\
\hline Individual & 54.4 & 78.4 & 52.8 & 24.7 & 27.9 & 47.8 & 55.4 & 31.2 & 37.2 \\
\hline Combined & 66.4 & 92.1 & 81.3 & 44.1 & 47.5 & 58.9 & 64.6 & 35.4 & 53.2 \\
\hline \multicolumn{10}{|c|}{ Services } \\
\hline \multicolumn{10}{|l|}{1995} \\
\hline Corporate & 10.3 & 16.2 & 43.8 & 38.7 & 25.4 & 11.6 & 5.2 & 17.3 & 12.2 \\
\hline Individual & 68.0 & 68.9 & 40.4 & 25.0 & 28.1 & 48.8 & 59.9 & 58.8 & 38.8 \\
\hline Combined & 78.2 & 85.1 & 84.3 & 63.7 & 53.5 & 60.4 & 65.1 & 76.1 & 51.0 \\
\hline \multicolumn{10}{|l|}{2000} \\
\hline Corporate & 10.0 & 15.8 & 27.5 & 27.0 & 18.7 & 8.1 & 5.4 & 4.9 & 12.2 \\
\hline Individual & 61.1 & 79.1 & 53.5 & 22.3 & 28.2 & 48.9 & 58.1 & 31.6 & 38.8 \\
\hline Combined & 71.1 & 94.9 & 81.0 & 49.3 & 46.9 & 57.0 & 63.5 & 36.4 & 51.0 \\
\hline \multicolumn{10}{|l|}{2001} \\
\hline Corporate & 9.5 & 15.6 & 19.5 & 26.4 & 19.3 & 8.2 & 5.5 & 4.3 & 12.2 \\
\hline Individual & 55.9 & 76.7 & 59.4 & 22.5 & 28.0 & 49.3 & 57.7 & 31.1 & 38.8 \\
\hline Combined & 65.4 & 92.3 & 78.9 & 48.9 & 47.3 & 57.6 & 63.1 & 35.5 & 51.0 \\
\hline
\end{tabular}

Note: A number of assumptions made in the calculation of METRs (e.g., economic depreciation, the real interest rate, the inflation rate and the share of different financing sources) imply that the estimated METRs could have been overestimated or underestimated in some cases.

Source: Authors' calculations. 
Table B5. Marginal effective tax rate for domestic investors, 1995, 2000 and 2001

The large-firm case, $100 \%$ equity financed

\begin{tabular}{|c|c|c|c|c|c|c|c|c|c|}
\hline & Canada & France & Germany & Italy & Japan & UK & US & Ireland & Sweden \\
\hline \multicolumn{10}{|c|}{ Manufacturing } \\
\hline \multicolumn{10}{|l|}{1995} \\
\hline Corporate & 49.3 & 50.2 & 77.1 & 58.7 & 52.4 & 40.4 & 43.9 & 12.2 & 29.6 \\
\hline Individual & 34.1 & 33.0 & 10.7 & 14.6 & 19.6 & 28.4 & 32.5 & 58.8 & 29.5 \\
\hline Combined & 83.4 & 83.1 & 87.8 & 73.3 & 72.0 & 68.8 & 76.4 & 70.9 & 59.2 \\
\hline \multicolumn{10}{|l|}{2000} \\
\hline Corporate & 48.8 & 55.2 & 68.6 & 43.4 & 42.0 & 37.9 & 44.7 & 11.5 & 29.6 \\
\hline Individual & 29.3 & 39.4 & 15.3 & 10.9 & 21.2 & 26.6 & 29.9 & 26.2 & 29.5 \\
\hline Combined & 78.1 & 94.5 & 83.8 & 54.4 & 63.2 & 64.5 & 74.5 & 37.7 & 59.2 \\
\hline \multicolumn{10}{|l|}{2001} \\
\hline Corporate & 48.7 & 51.8 & 56.3 & 42.5 & 43.7 & 37.7 & 44.9 & 10.7 & 29.6 \\
\hline Individual & 24.7 & 38.9 & 21.2 & 11.1 & 20.6 & 27.6 & 29.2 & 25.4 & 29.5 \\
\hline Combined & 73.4 & 90.7 & 77.5 & 53.6 & 64.3 & 65.3 & 74.1 & 36.2 & 59.2 \\
\hline \multicolumn{10}{|c|}{ Services } \\
\hline \multicolumn{10}{|l|}{1995} \\
\hline Corporate & 54.2 & 51.1 & 72.2 & 60.5 & 52.0 & 36.4 & 43.5 & 39.7 & 26.9 \\
\hline Individual & 30.8 & 32.3 & 13.0 & 14.0 & 19.7 & 30.3 & 32.7 & 40.3 & 30.7 \\
\hline Combined & 85.0 & 83.5 & 85.2 & 74.5 & 71.8 & 66.7 & 76.2 & 80.0 & 57.6 \\
\hline \multicolumn{10}{|l|}{2000} \\
\hline Corporate & 53.8 & 55.9 & 62.4 & 46.4 & 41.7 & 33.9 & 44.1 & 24.6 & 26.9 \\
\hline Individual & 26.5 & 38.7 & 18.3 & 10.4 & 21.3 & 28.4 & 30.2 & 22.3 & 30.7 \\
\hline Combined & 80.3 & 94.6 & 80.7 & 56.8 & 63.0 & 62.3 & 74.3 & 46.9 & 57.6 \\
\hline \multicolumn{10}{|l|}{2001} \\
\hline Corporate & 52.7 & 52.7 & 49.5 & 45.5 & 43.4 & 33.7 & 44.3 & 19.9 & 26.9 \\
\hline Individual & 22.8 & 38.2 & 24.5 & 10.6 & 20.7 & 29.3 & 29.5 & 22.8 & 30.7 \\
\hline Combined & 75.5 & 90.9 & 74.1 & 56.0 & 64.1 & 63.1 & 73.8 & 42.7 & 57.6 \\
\hline
\end{tabular}


Table B6. Marginal effective tax rate for domestic investors, 1995, 2000 and 2001

The small firm case, $100 \%$ equity financed

\begin{tabular}{|c|c|c|c|c|c|c|c|c|c|}
\hline & Canada & France & Germany & Italy & Japan & UK & US & Ireland & Sweden \\
\hline \multicolumn{10}{|c|}{ Manufacturing } \\
\hline 1995 & & & & & & & & & \\
\hline Corporate & 30.1 & 50.2 & 77.1 & 58.7 & 42.6 & 31.5 & 9.7 & 12.2 & 29.6 \\
\hline Individual & 47.0 & 33.0 & 10.7 & 14.6 & 23.6 & 32.6 & 52.3 & 58.8 & 29.5 \\
\hline Combined & 77.1 & 83.1 & 87.8 & 73.3 & 66.2 & 64.1 & 62.0 & 70.9 & 59.2 \\
\hline \multicolumn{10}{|l|}{2000} \\
\hline Corporate & 28.9 & 41.9 & 68.6 & 39.2 & 34.3 & 25.5 & 10.4 & 11.5 & 29.6 \\
\hline Individual & 40.7 & 51.0 & 15.3 & 11.8 & 24.0 & 32.0 & 48.4 & 26.2 & 29.5 \\
\hline Combined & 69.6 & 92.9 & 83.8 & 51.0 & 58.4 & 57.4 & 58.8 & 37.7 & 59.2 \\
\hline \multicolumn{10}{|l|}{2001} \\
\hline Corporate & 28.5 & 43.4 & 56.3 & 38.3 & 35.2 & 25.3 & 10.6 & 10.7 & 29.6 \\
\hline Individual & 34.4 & 45.7 & 21.2 & 12.0 & 23.7 & 33.1 & 47.4 & 25.4 & 29.5 \\
\hline Combined & 62.9 & 89.1 & 77.5 & 50.2 & 58.9 & 58.4 & 57.9 & 36.2 & 59.2 \\
\hline \multicolumn{10}{|c|}{ Services } \\
\hline \multicolumn{10}{|l|}{1995} \\
\hline Corporate & 27.7 & 51.1 & 72.2 & 60.5 & 42.3 & 28.2 & 5.8 & 39.7 & 26.9 \\
\hline Individual & 48.7 & 32.3 & 13.0 & 14.0 & 23.7 & 34.2 & 54.6 & 40.3 & 30.7 \\
\hline Combined & 76.3 & 83.5 & 85.2 & 74.5 & 66.0 & 62.4 & 60.3 & 80.0 & 57.6 \\
\hline \multicolumn{10}{|l|}{2000} \\
\hline Corporate & 26.6 & 43.1 & 62.4 & 42.3 & 34.2 & 23.0 & 6.2 & 12.9 & 26.9 \\
\hline Individual & 42.1 & 49.9 & 18.3 & 11.2 & 24.1 & 33.0 & 50.7 & 25.8 & 30.7 \\
\hline Combined & 68.7 & 93.0 & 80.7 & 53.5 & 58.3 & 56.0 & 56.8 & 38.7 & 57.6 \\
\hline \multicolumn{10}{|l|}{2001} \\
\hline Corporate & 26.1 & 44.6 & 49.5 & 41.4 & 35.1 & 22.8 & 6.3 & 12.5 & 26.9 \\
\hline Individual & 35.5 & 44.7 & 24.5 & 11.4 & 23.7 & 34.2 & 49.6 & 24.9 & 30.7 \\
\hline Combined & 61.7 & 89.3 & 74.1 & 52.7 & 58.8 & 57.0 & 55.9 & 37.4 & 57.6 \\
\hline
\end{tabular}

Note: A number of assumptions made in the calculation of METRs (e.g., economic depreciation, the real interest rate, the inflation rate and the share of different financing sources) imply that the estimated METRs could have been overestimated or underestimated in some cases.

Source: Authors' calculations. 


\section{REFERENCES}

American Council for Capital Formation (1999), "An International Comparison of Death Tax Rates", Special Report, American Council for Capital Formation Center for Policy Research, Washington, DC.

Arthur Andersen (2001), Canada and Provinces Budget Briefings 2001, Toronto, Canada.

Auerbach, Alan J. (2001), "Taxation and Corporate Financial Policy", forthcoming in Auerbach, Alan J. and Martin Feldstein (eds.), Handbook of Public Economics, Vol. III, North-Holland, Amsterdam, the Netherlands.

Baran, Joni (1996), "Payroll Taxation and Employment: A Literature Survey", Industry Canada Occasional Paper No. 15, Ottawa, Canada.

Blau, David M. (1987), “A Time-Series Analysis of Self-Employment in the United States”, Journal of Political Economy, Vol. 95, No. 3, pp. 445-467.

Blumenthal, Marsha, Charles Christian and Joel Slemrod (1998), "The Determinants of Income Tax Compliance: Evidence from a Controlled Experiment in Minnesota", NBER Working Paper, No. 6575, NBER, Cambridge, MA.

Boadway, Robin and Neil Bruce (1992), "Problems with Integrating Corporate and Personal Income Taxes in an Open Economy", Journal of Public Economics, Vol. 48, pp. 39-66.

Boadway, Robin, Neil Bruce and Jack Mintz (1984), "Taxation, Inflation and the Marginal Tax Rate on Capital in Canada", Canadian Journal of Economics, Vol. 17, pp. 62-79.

Bronchi, Chiara (2001), "Options for Reforming the Tax System in Greece”, Economics Department Working Papers No. 291, OECD, Paris.

Bronchi, Chiaira and Andrew Burns (2000), "The Tax System in the Czech Republic", Economics Department Working Papers No. 245, OECD, Paris.

Bronchi, Chiara and José C. Gomes-Santos (2001), "Reforming the Tax System in Portugal", Economics Department Working Papers No. 302, OECD, Paris.

Bruce, Donald (2000), "Effects of the United States Tax System on Transitions into Self-employment", Labour Economics, Vol. 7, No. 5, pp. 545-574.

Bruce, Donald (2001), "Taxes and Entrepreneurial Endurance: Evidence from the Self-Employed", Center for Business and Economic Research and Department of Economics, University of Tennessee, mimeo.

Bruce, David and Douglas Holtz-Eakin (2001), "Taxes and the Allocation of Entrepreneurial Effort", University of Tennessee and Syracuse University, mimeo.

Burman, Leonard E. (1999), The Labyrinth of Capital Gains Tax Policy, Brookings Institution Press, Washington, DC. 
Carey, David, Kathryn Gordon and Philippe Thalmann (1999), "Tax Reform in Switzerland”, Economics Department Working Papers No. 222, OECD, Paris.

Carroll, Robert, Douglas Holtz-Eakin, Mark Rider and Harvey S. Rosen (2000a), "Entrepreneurs, Income Taxes, and Investment", in Joel B., Slemrod (ed.), Does Atlas Shrug?, Harvard University Press, Cambridge, MA., pp. 427-455.

Carroll, Robert, Douglas Holtz-Eakin, Mark Rider and Harvey S. Rosen (2000b), "Income Taxes and Entrepreneurs' Use of Labor", Journal of Labor Economics, Vol. 18, No. 2, pp. 324-351.

Carroll, Robert, Douglas Holtz-Eakin, Mark Rider and Harvey S. Rosen (2001), "Personal Income Taxes and the Growth of Small Firms", in Poterba, James, ed., Tax Policy and the Economy, Vol. 15, MIT Press, Cambridge, MA.

Carroll, Robert and David Joulfaian (1997), "Taxes and Corporate Choice of Organizational Form", Office of Tax Analysis Paper 73, U.S. Treasury Department, Washington, D.C.

Dalsgaard, Thomas (2000a), "The Tax System in Korea: More Fairness and Less Complexity Required", Economics Department Working Papers No. 271, OECD, Paris.

Dalsgaard, Thomas (2000b), "The Tax System in Mexico: A Need for Strengthening the Revenue-Raising Capacity”, Economics Department Working Papers No. 233, OECD, Paris.

Dalsgaard, Thomas (2001), "The Tax System in New Zealand: An Appraisal and Options for Change", Economics Department Working Papers No. 281, OECD, Paris.

Dalsgaard, Thomas and Masaaki Kawagoe (2000), "The Tax System in Japan: A Need for Comprehensive Reform”, Economics Department Working Papers No. 231, OECD, Paris.

Engen, Eric and Jonathan Skinner (1996), "Taxation and Economic Growth", National Tax Journal, Vol. 49, No. 4, pp. 617-642.

Erard, Brian (1997), "The Income Tax Compliance Burden on Small and Medium-sized Canadian Businesses", Technical Committee on Business Taxation Working Paper 97-12, Department of Finance, Government of Canada, Ottawa.

Ernst \& Young (2000a), The Global Executive, New York.

Ernst \& Young (2000b), Worldwide Corporate Tax Guide, New York.

Ernst \& Young (2001a), The Global Executive, New York.

Ernst \& Young (2001b), Worldwide Corporate Tax Guide, New York.

Evans, David S. and Linda S. Leighton (1989), "The Determinants of Changes in U.S. Self-Employment, 1968-1987”, Small Business Economics, Vol. 1, pp. 111-119.

Fairlie, Robert W. and Bruce D. Meyer (1999), "Trends in Self-Employment Among White and Black Men”, NBER Working Paper No. 7182, Cambridge, MA.

Gentry, William M. and R. Glenn Hubbard (2000), "Tax Policy and Entrepreneurial Entry", American Economic Review, Vol. 90, No. 2, pp. 283-287. 
Gompers, Paul A. and Josh Lerner (1999), “What Drives Venture Capital Fundraising?”, NBER Working Paper No. 6909, National Bureau of Economic Research, Cambridge, MA.

Gordon, Roger H. (1998), "Can high Personal Tax Rates Encourage Entrepreneurial Activity?", IMF Staff Papers, Vol. 45, No. 1, pp. 49-80.

Gravelle, Jane G. (1994), The Economic Effects of Taxing Capital Income, MIT Press, Cambridge, MA.

Hendricks, Kenneth, Raphael Amit and Diana Whistler (1997), "Business Taxation of Small and Mediumsized Enterprises in Canada", Technical Committee on Business Taxation Working Paper 97-11, Department of Finance, Government of Canada, Ottawa.

Herd, Richard and Chiara Bronchi (2001), "Increasing Efficiency and Reducing Complexity in the Tax System in the United States", Economics Department Working Papers No. 313, OECD, Paris.

Herd, Richard and Thorsteinn Thorgeirsson (2001), "Increasing Simplicity, Neutrality and Sustainability: A Basis for Tax Reform in Iceland", Economics Department Working Papers No. 392, OECD, Paris.

Holtz-Eakin, Douglas and Donald Marples (2001), "Estate Taxes, Labor Supply, and Economic Efficiency", Special Report, American Council for Capital Formation Center for Policy Research, Washington, DC.

Holtz-Eakin, Douglas and Harvey S. Rosen (2001), "Economic Policy and the Start-up, Survival, and Growth of Entrepreneurial Ventures", Office of Advocacy Contract Research No. 206, US Small Business Administration, Washington D.C.

Holtz-Eakin, Douglas, David Joulfaian and Harvey S. Rosen (1994a), "Entrepreneurial Decisions and Liquidity Constraints", RAND Journal of Economics, Vol. 25, pp. 334-347.

Holtz-Eakin, Douglas, David Joulfaian and Harvey S. Rosen (1994b), "Sticking It Out: Entrepreneurial Decisions and Liquidity Constraints", Journal of Political Economy, Vol. 102, pp. 53-75.

Hubbard, Glenn (1993), "Corporate Tax Integration: A View From the Treasury Department", Journal of Economic Perspectives, Vol. 7, No. 1, pp. 115-132.

International Bureau of Fiscal Documentation (2001), Annual Report, 2000-2001: Including worldwide survey of trends and development in taxation, Amsterdam and Valatie, NY.

Joulfaian, David and Mark Rider (1998), "Differential Taxation and Tax Evasion by Small Business", National Tax Journal, Vol. 51, No. 4, pp. 675-687.

Joumard, Isabelle and Aristomène Varoudakis (2000), "Options for Reforming the Spanish Tax System", Economics Department Working Papers No. 249, OECD, Paris.

Joumard, Isabelle (2001), "Tax Systems in European Union Countries", Economics Department Working Papers No. 301, OECD, Paris.

Keen, Michael and Jack Minttz (2000), "The Optimal Threshold for A Value-Added Tax", International Monetary Fund and University of Toronto, mimeo.

King, Mervyn (1977), Public Policy and the Corporation, Chapman and Hall, London. 
Leibfritz, Willi, John Thoronton and Alexandra Bibbee (1997), "Taxation and Economic Performance", Economics Department Working Papers No. 176, OECD, Paris.

Lenain, Patric and Leszek Bartoszuk (2000), “The Polish Tax Reform”, Economics Department Working Papers No. 234, OECD, Paris.

Lin, Zhengxi (2001), "Payroll Taxes in Canada Revisited: Structure, Statutory Parameters, and Recent Trends", Analytical Studies Branch Research Paper No. 149, Statistics Canada, Ottawa.

Long, James E. (1982), "The Income Tax and Self-employment", National Tax Journal, Vol. 35, pp. 31-42.

Messerre, Ken (ed.) (1998), The Tax System in Industrialized Countries, Oxford University Press, Oxford, United Kingdom.

Ministry of Finance (2000), “FY 2001 Tax Reform (Main Points)”, Ministry of Finance, Japan.

McKenzie, Kenneth J. and Aileen J. Thompson (1996), “The Economic Effects of Dividend Taxation”, Technical Committee on Business Taxation Working Paper 96-7, Department of Finance, Government of Canada, Ottawa.

Mintz, Jack M. and Thomas A. Wilson (2000), "Capitalizing on Cuts to Capital Gains Taxes", C.D. Howe Institute Commentary, No. 137, Toronto, Canada.

Modigliani, Franco and Merton H. Miller (1958), "The Cost of Capital, Corporation Finance, and the Theory of Investment”, American Economic Review, Vol. 48, pp. 261-297.

OECD (1991), Taxing Profits in a Global Economy, OECD, Paris.

OECD (2000), Economic Surveys Italy, OECD, Paris.

OECD (2001a), “Intangible Investment, Growth and Policy”, DSTI/IND(2001)5, OECD, Paris.

OECD (2001b), Revenue Statistics, OECD, Paris.

OECD (2001c), Science, Technology and Industry Outlook, Drivers of Growth: Information Technology, Innovation and Entrepreneurship, OECD, Paris.

OECD (2001d), The New Economy: Beyond the Hype, OECD, Paris.

OECD (2001e), The OECD Tax Database, OECD, Paris.

Parker, Simon C. (1996), "A Time Series Model of Self-employment under Uncertainty", Economica, Vol. 63, pp. 459-475.

Plamondon \& Associates INC. (1996), "Compliance Issues: Small Business and the Corporate Income Tax System", Technical Committee on Business Taxation Working Paper 96-9, Department of Finance, Government of Canada, Ottawa.

Poterba, James M. (2001), "Taxation, Risk-Taking and Household Portfolio Behaviour", Forthcoming in Auerbach, Alan J. and Martin Feldstein, eds., Handbook of Public Economics, Vol. III, NorthHolland, Amsterdam, the Netherlands. 
Robson, Martin T. (1998), "The Rise in Self-Employment Amongst UK Males", Small Business Economics, Vol. 10, pp. 199-212.

Robson, Martin T. and Colin Wren (1999), "Marginal and Average Tax Rates and the Incentive for SelfEmployment”, Southern Economic Journal, Vol. 65, No. 4, pp. 757-773.

Sandford, C. (1989), "Administrative and Compliance Costs of Taxation", Fiscal Publications, Bath, England.

Shome, Parthasathi, (ed.) (1995), Tax Policy Handbook, Tax Policy Division, Fiscal Affairs Department, International Monetary Fund, Washington, DC.

Van den Noord, Paul and Christopher, Heady (2001), "Surveillance of Tax Policies: A Synthesis of Findings in Economic Surveys", Economics Department Working Papers No. 303, OECD, Paris. 